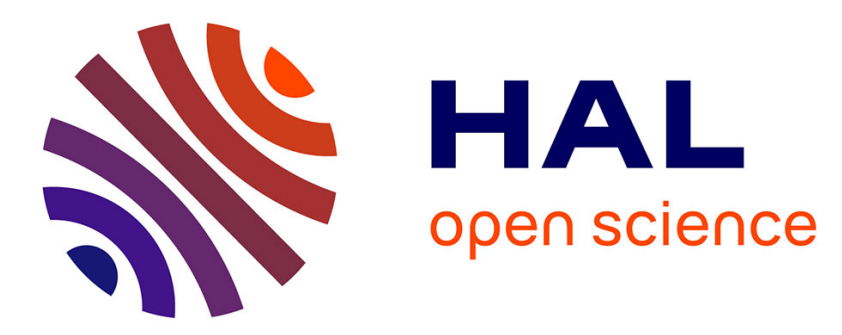

\title{
Relationships between heavy metals distribution and organic matter cycling in mangrove sediments (Conception Bay, New Caledonia)
}

\author{
Cyril Marchand, M. Allenbach, Elisabeth Lallier-Vergès
}

\section{To cite this version:}

Cyril Marchand, M. Allenbach, Elisabeth Lallier-Vergès. Relationships between heavy metals distribution and organic matter cycling in mangrove sediments (Conception Bay, New Caledonia). Geoderma, 2011, 160 (3-4), pp.444-456. 10.1016/j.geoderma.2010.10.015 . insu-00536395

\section{HAL Id: insu-00536395}

\section{https://hal-insu.archives-ouvertes.fr/insu-00536395}

Submitted on 28 Jan 2011

HAL is a multi-disciplinary open access archive for the deposit and dissemination of scientific research documents, whether they are published or not. The documents may come from teaching and research institutions in France or abroad, or from public or private research centers.
L'archive ouverte pluridisciplinaire HAL, est destinée au dépôt et à la diffusion de documents scientifiques de niveau recherche, publiés ou non, émanant des établissements d'enseignement et de recherche français ou étrangers, des laboratoires publics ou privés. 
Relationships between heavy metals distribution and organic matter cycling in mangrove sediments

(Conception Bay, New-Caledonia)

C. Marchand ${ }^{1 *}$, M. Allenbach ${ }^{2}$, E. Lallier-Vergès ${ }^{3}$,

${ }^{1}$ Institut de Recherche pour le Développement (IRD), UR 206/ UMR 7590 IMPMC, Nouméa, New-

Caledonia.

${ }^{2}$ PPME, EA 3325, Université de la Nouvelle-Calédonie, Nouméa, New-Caledonia.

${ }^{3}$ Institut des Sciences de la Terre d'Orléans, CNRS-Université d'Orléans, Géosciences, 45067 Orléans, France.

*Corresponding author

E-mail address: cyril.marchand@ird.fr 


\section{Abstract}

Mangroves of New-Caledonia act as a buffer between a lagoon of more than $20,000 \mathrm{~km}^{2}$ and the Island, which suffers intense processes of erosion resulting from urbanization and natural resources exploitation. This preliminary study aims at determining how heavy metals are distributed in mangrove sediments and pore-waters in relationship with their organic content. To reach our goal, a series of 50-cm deep cores were collected in the mangrove of Conception Bay. The various coring sites are representative of live forests (Avicennia marina, Rhizophora stylosa), dead forest, and intertidal unvegetated area. The ranges of concentrations in sediments were the following $\left(\mu \mathrm{mol} \mathrm{g}^{-1}\right)$ : $\mathrm{Cu}$ (0.08 to 0.51$)$, Co (0.01 to 0.38$)$, Ni (0.03 to 3.55), $\mathrm{Cr}$ (0.36 to 3.11), $\mathrm{Zn}$ (0.68 to 2.36), $\mathrm{Mn}$ (1.13 to 5.0) and Fe (22.64 to 721.69). Heavy metals distribution within sediments and pore-water appear to result from diagenetic processes linked to OM decomposition. Beneath the dead Avicennia forest and in the unvegetated sediments, the higher the organic content, the higher the metal concentration in the solid phase. Beneath living mangrove stands, despite a higher organic content, as well as higher sulphur content, heavy metals concentrations were not higher than those measured in the other sampling sites. Beneath these forests, redox conditions were mainly controlled by the length of waterlogging and the activity of root-system. We suggest that, because of the specificity of the Avicennia root system and its position in the intertidal zone, heavy metals are more bioavailable and potentially more mobile than beneath Rhizophora stand.

Keywords: mangrove, heavy metals, organic matter, redox conditions, New-Caledonia 


\section{Introduction}

Mangroves are specific intertidal ecosystems, covering between 160,000 and 200,000 $\mathrm{km}^{2}$ along more than $70 \%$ of tropical and subtropical coastlines (Spalding et al., 1997; FAO, 2003). Mangroves comprise close to 80 species worldwide from around 20 families of vascular plants (Tomlinson, 1986). This ecosystem is highly rich in biodiversity, and act as a habitat for many species (Nagelkerken et al., 2008). Mangrove forests are among the most productive terrestrial ecosystems, with a NPP estimated at $149 \mathrm{~mol} \mathrm{C} \mathrm{m} \mathrm{y}^{-1}$, providing food sources for local faunal communities and also adjacent coastal foodwebs (Kristensen et al., 2008; Bouillon et al., 2008). Nevertheless, resulting from demographic increase, urbanization increase, expansion of industrial activities, natural resources prospecting and exploitation, mangroves are disappearing at an alarming rate (Duke et al., 2007). Due to their persistence, potential toxicity, and bioavailability, heavy metals represent a major threat for mangrove biodiversity and also for human health. Additionally to their anthropogenic origin (e.g. mining activities, industries, etc.), natural processes, such as geologic weathering of soils and rocks, increase their occurrence. Heavy metals are transported by water or wind to coastal areas, where they can be deposited as sediments. Because of the capacity of mangroves to efficiently trap suspended material from the water column (Furukawa et al., 1997), and the high affinity of organic matter (OM) for heavy metals (Nissenbaum and Swaine, 1976), mangrove sediments have a large capacity to accumulate these pollutants (Lacerda et al., 1988; Tam and Wong, 2000). Ramos et al. (2006) suggested that mangrove trees can be considered as a biochemical reactors, not only because of their physiological and biochemical processes but also due to their active role in organic matter decomposition within the sediments that greatly influence the mobility of heavy metals. Mangroves can act as a long term sink for heavy metals because of their precipitation with sulfides during diagenetic reactions and the relative stability of these minerals (Huerta-Diaz and Morse, 1992). However, mangrove organic-rich sediments are subjected to various diagenetic processes. Sulfate reduction is thought to be the dominant process, but aerobic respiration and also Fe and Mn respiration can be important OM decomposition pathways in mangrove sediments (Alongi et al., 1998; 2000; Kristensen, 2000). Decay processes vary spatially and temporally as a result of various factors, such as the ability of root system 
to diffuse air into the sediment, intense faunal bioturbation, and seasonal alternation of water logging (Scholander et al., 1955; Clark et al., 1998; Marchand et al., 2004; Marchand et al., 2006). This variability may induce changes in heavy metals distribution between dissolved and particulate phases, and thus changes of their toxicity. As an example, metals in pore-waters are more bioavailable than ones adsorbed on mineral surfaces, and can be easier uptake by organisms, thus entering foodwebs. As a consequence, mangrove sediments may shift from a heavy metals sink to a heavy metals source for adjacent systems (Harbison, 1986). In New-Caledonia, mangroves are associated with a lagoon of more than 20,000 $\mathrm{Km}^{2}$, delimitated by an almost continuous coral barrier reef of over $1500 \mathrm{~km}$ in total length. Extensive mangrove are fringing $80 \%$ of the western coastline of the Island and $20 \%$ of the eastern's. As a consequence of their distribution, mangroves represent a major source of nutrients for the lagoon. Nevertheless, the economic development of the Island increases the pressure on mangrove environment. New-Caledonia is currently the $3^{\text {rd }}$ nickel producing countries in the world. Anthropogenic pressure can be expressed following two main ways. The former corresponds to the construction of road and buildings, i.e. urbanization, and the latter is the mining activities (Ni-ore) occurring in lateritic soils located upstream mangrove areas. Processes of erosion and sedimentation along the coastline, and which occur naturally, are strongly amplified by mining activities and urbanization (Fernandez et al., 2006). The purpose of this preliminary study was to understand the distribution of some heavy metals ( $\mathrm{Cr}, \mathrm{Mn}, \mathrm{Fe}, \mathrm{Co}, \mathrm{Ni}, \mathrm{Cu}, \mathrm{Zn})$ in sediments and pore-waters in an urban mangrove, where the catchment do not contain significant Ni occurrence, but had suffered erosion resulting from urbanization. In this context, we were interested in the relationships between mangrove stands, sedimentary organic matter, pore-water parameters and heavy metals concentrations. To reach our goal, quantitative analyses, e.g. Rock-Eval and HR-ICP-OES, were carried out on cores collected beneath 2 living mangrove stands (Avicennia marina and Rhizophora stylosa), a dead mangrove, and in intertidal unvegetated sediments. These data would also provide some baseline information on the variability of heavy metal concentrations in New-Caledonian mangrove substrate, and will be useful for further studies on mangroves that are situated downstream Ni exploitation areas. 


\section{Materials and Methods}

\subsection{Study site and sampling}

New-Caledonia, which is situated in the South Pacific Ocean, is orientated along a northwestsoutheast axis, and is almost $500 \mathrm{~km}$ in length and about $50 \mathrm{~km}$ in wide (Fig. 1). The main island $\left(20^{\circ} \mathrm{S}-23^{\circ} \mathrm{S}\right)$ is characterized by a tropical climate, strongly influenced by the ITCZ cycling, with mean annual rainfall close to $1100 \mathrm{~mm}$, and average monthly air temperatures fluctuating between 20 and $27^{\circ}$. Work was carried out during the dry season in September 2005. The studied mangrove is located in Conception Bay, which is close to Noumea, the main city of New-Caledonia.

Samples studied herein come from 5 mangrove areas defined in terms of vegetation composition: 2 Avicennia marina forests, 2 Rhizophora stylosa forests, and a dead Avicennia forest with standing dead trees. In addition, cores were collected in the intertidal unvegetated sediment.

Cores (50 cm deep) were performed at low tide with an Eijkelkamp gouge auger along 2 transects. Elevation related to mean sea level was measured on both transects, allowing determining elevation differences between sampling sites. This survey was realized using a theodolite with an electronic distance measurement device, and was started from a benchmark on the road crossing the mangrove (Fig. 1). Mean values of metals concentrations in sediments, presented in table 1, were calculated using all the samples, in order to make global comparison with other locations. To compare the various areas studied herein, results of one core per site for each parameter is presented; the redox profiles of the twin cores being very similar. In the A. marina forest, core locations were chosen equidistant from trees, in consideration of the large extension of the radial cable roots. In the $R$. stylosa forest, cores were collected under prop roots. After being collected, cores were wrapped in plastic film and aluminum foil in order to limit gaseous exchanges. Back at the lab (less than 1 hour after cores collection), samples were collected every $2 \mathrm{~cm}$ from 0 to $20 \mathrm{~cm}$ depth, every $5 \mathrm{~cm}$ from 20 to $50 \mathrm{~cm}$ depth. Subsamples for trace metals analyses were collected at the center of cores on the whole thickness. Until drying, samples were kept frozen. Then, they were grounded with an agate pestle and mortar. 
Pore-waters were extracted, at the lab, on the day of coring with soil moisture sampler Rhizon ${ }^{\circledR}$ (Song et al., 2003), which were directly inserted into a piece of core from the gouge auger. The sampler is connected to a syringe using luer-lock fittings and PVC tubing. Evacuating the syringe by drawing the piston allows collecting pore-water from sediments. After 2 hours, the output was around $20 \mathrm{ml}$ of pore-water for a piece of core of $150 \mathrm{~cm}^{3}$. All samples were then immediately filtered through 0.45 $\mu \mathrm{m}$ Sartorius ${ }^{\circledR}$ filters and acidified to $\mathrm{pH} 2$ with Suprapur ${ }^{\circledR} \mathrm{HNO}_{3}$. Samples were stored in cleaned 14 $\mathrm{ml}$ polypropylene tubes, in a cold room $\left(\mathrm{T}=4^{\circ} \mathrm{C}\right)$ until analysis.

\subsection{Analytical methods}

\subsubsection{Salinity, $\mathrm{pH}$ and redox measurements}

Physico-chemical parameters were determined in an air-conditioned laboratory a couple of hours after coring. Salinities were determined using an Atago refractometer after extracting a drop of pore-water from the core. $\mathrm{pH}$ was measured using a glass electrode and a WTW $\mathrm{pH}$ meter. The $\mathrm{pH}$ electrode was calibrated using 4 and 7 standards (NIST scale). Redox potential was measured, using a combined Pt and $\mathrm{Ag} / \mathrm{AgCl}$ (reference) electrode connected to a WTW $\mathrm{pH} / \mathrm{mV} / \mathrm{T}$ meter. The redox electrode was periodically checked using a $0.43 \mathrm{~V}$ standard solution and demineralized water. Probes were directly inserted into the mud until stable values were reached, then were thoroughly washed. Redox data are reported relative to a standard hydrogen electrode, i.e., after adding $202 \mathrm{mV}$ to the original $\mathrm{mV}$ values obtained with an $\mathrm{Ag} / \mathrm{AgCl}$ reference electrode (at $25^{\circ} \mathrm{C}$ ). The redox scale used in this study is:

- Oxic > $400 \mathrm{mV}$, contain measurable dissolved oxygen.

- $100 \mathrm{mV}<$ Suboxic $<400 \mathrm{mV}$, lack measurable oxygen or sulfide, but contain dissolved iron or manganese, no reduction of sulfate.

- Anoxic $<100 \mathrm{mV}$, sulfate reduction.

\subsubsection{Rock-Eval analyses}


Total Organic Carbon (TOC) was determined using a Rock-Eval 6 pyrolysis on powdered rock samples (Lafargue et al., 1998). In the R-E 6, samples are first pyrolysed under inert nitrogen atmosphere, and the residual carbon is subsequently burnt in an oxidation oven. The pyrolysis programme is: $200^{\circ} \mathrm{C}(2 \mathrm{~min})$, then to $650^{\circ} \mathrm{C}$ at $30^{\circ} \mathrm{C} \min ^{-1}$ (hold $3 \mathrm{~min}$ ). The oxidation phase starts with an isothermal stage at $400^{\circ} \mathrm{C}$, followed by an increase to $850^{\circ} \mathrm{C}$ at $30^{\circ} \mathrm{C} \min ^{-1}$ (hold $5 \mathrm{~min}$ ). TOC is determined as the sum of pyrolysed and residual organic carbon contents. In the present study, two others Rock-Eval parameters are used, the hydrogen index (HI) and the oxygen index (OIRE6). HI corresponds to the quantity of hydrocarbon (HC) released during pyrolysis relative to TOC, expressed in mg $\mathrm{HC} \mathrm{g}^{-1}$ TOC. It is correlated with $\mathrm{H} / \mathrm{C}$ ratios. OIRE6, which is correlated with $\mathrm{O} / \mathrm{C}$ ratios, corresponds to the quantity of oxygen released as $\mathrm{CO}$ and $\mathrm{CO}_{2}$ during pyrolysis, relative to TOC. It is expressed in $\mathrm{mg} \mathrm{O}_{2} \mathrm{~g}^{-1}$ TOC.

\subsubsection{Total Nitrogen and Total sulfur}

Total nitrogen and total sulfur (TS) concentrations were measured by combustion at $1100{ }^{\circ} \mathrm{C}$ with a CNS-2000 LECO apparatus. C/N ratios were then determined to characterize OM quality.

\subsubsection{Major elements}

Major elements $\left(\mathrm{SiO}_{2}, \mathrm{TiO}_{2}, \mathrm{Al}_{2} \mathrm{O}_{3}, \mathrm{Fe}_{2} \mathrm{O}_{3}, \mathrm{MnO}, \mathrm{MgO}, \mathrm{CaO}, \mathrm{Na}_{2} \mathrm{O}, \mathrm{K}_{2} \mathrm{O}, \mathrm{P}_{2} \mathrm{O}_{5}\right.$, in \% weight) were determined by Inductively Coupled Plasma Optical Emission Spectrometry (ICP-OES) after classical digestion. $100 \mathrm{mg}$ of sample was fused at $1,000{ }^{\circ} \mathrm{C}$ with $1 \mathrm{~g}$ of $\mathrm{LiBO}_{2}$ for about 30 minutes. The fusion residue was then dissolved with $5 \% \mathrm{HCl} .4$ samples per core were chosen for analyzes as a function of $\mathrm{pH}$ and redox depth trends. $\mathrm{Si} / \mathrm{Al}$ ratios were then determined.

\subsubsection{Trace elements}

The concentrations of $\mathrm{Fe}, \mathrm{Mn}, \mathrm{Cr}, \mathrm{Co}, \mathrm{Cu}, \mathrm{Ni}$, and $\mathrm{Zn}$, expressed in $\mu \mathrm{mol} \mathrm{g}^{-1}$, were determined on a Jobin-Yvon HR-ICP-AES after microwave digestion. A $10 \mathrm{ml}$ volume of a mixture of Suprapur ${ }^{\circledR}$ $\mathrm{HCl}, \mathrm{HNO}_{3}$ and $\mathrm{H}_{2} \mathrm{O}$ (1:1:1) was added to $100 \mathrm{mg}$ of sample. The whole was placed in Teflon vessels, 
previously washed with concentrated nitric acid. Samples were digested in a MDS 2000 (CEM Corp. ${ }^{\circledR}$ ) microwave at $100 \%$ power with pressure set at $0.83 \mathrm{Mpa}$, temperature set at $165^{\circ} \mathrm{C}$, and for 30 min. 6 to 7 samples per core were chosen for analyses as a function of $\mathrm{pH}$ and redox depth trends. At least 1 sample by redox conditions was analyzed. Blank acid mixtures were digested in the same way. Each sample was measured in triplicate with mean standard deviation for $\mathrm{Fe}, \mathrm{Mn}, \mathrm{Cr}, \mathrm{Cu}, \mathrm{Co}, \mathrm{Ni}, \mathrm{Zn}$ less than $2 \%, 1 \%, 2 \%, 5 \%, 5 \%, 5 \%$, and $2 \%$ respectively. Accuracy of the measurements was checked by analysis of an estuarine sediment certified reference material (LGC 6137) (Tab. 2). Analytical results obtained for references materials differed by less than $15 \%$ from the certified values.

Dissolved Fe, Mn, Cr, and Ni concentrations, expressed in $\mu \mathrm{mol}^{-1}$, were also measured in triplicate on pore-water samples. 4 to 7 samples per core were chosen for analyses as a function of redox depth trends.

\section{Results}

\subsection{Intertidal unvegetated area}

Concerning the core collected in the unvegetated area, depth trends of the various parameters are presented in Fig. 2. Heavy metal concentrations ranged as follow (in $\mu \mathrm{mol} \mathrm{g}^{-1}$ ): Fe from 232 to 440; Mn from 2.7 to 5; Zn from 0.8 to 2.4; Cr from 0.4 to 2; $\mathrm{Ni}$ from 0.3 to 1.7 ; $\mathrm{Cu}$ from 0.1 to 0.5 ; Co from 0.1 to 0.2 . Their distribution with depth as well the distribution of most of the various sediment characteristics indicated three distinctive layers developing from the top to $6 \mathrm{~cm}$ depth, from 6 to 26 cm depth, and below $26 \mathrm{~cm}$ depth. The highest heavy metals concentrations were measured in the intermediate layer. This layer was also characterized by the highest TOC and $\mathrm{C} / \mathrm{N}$ values, reaching $3 \%$, and 20, respectively. The upper and the deeper layers were characterized by mean TOC and C/N values close to 0.7 and 8 , respectively (Fig. 2a). HI were low on the whole depth profile, with values lower than 150 mg HC g $\mathrm{g}^{-1}$ TOC, while OIRE6 increased in the deeper layer, reaching $300 \mathrm{mg} \mathrm{O}_{2} \mathrm{~g}^{-1}$ TOC at $50 \mathrm{~cm}$ depth (Fig. 2b). pH values were stable on the whole depth profile, with a mean value close to 7.4. Conversely, redox conditions strongly varied between the three layers (Fig. 2e). In the 
upper $6 \mathrm{~cm}$, suboxic conditions were evidenced by Eh values close to $200 \mathrm{mV}$, dissolved $\mathrm{Fe}$ concentrations close to $10 \mu \mathrm{mol} \mathrm{l}^{-1}$ and total sulfur (TS) concentrations lower than $200 \mu \mathrm{mol} \mathrm{g}^{-1}$ (Fig. 2f). The intermediate layer was characterized by anoxic and slightly sulfidic conditions, with Eh values ranging between $-200 \mathrm{mV}$ and $100 \mathrm{mV}$, dissolved Fe concentrations lower than $0.5 \mu \mathrm{mol} \mathrm{l}{ }^{-1}$, and TS concentrations reaching $400 \mu \mathrm{mol} \mathrm{g}{ }^{-1}$. Finally at depth, redox values and TS concentrations were close to those of the upper $6 \mathrm{~cm}$, but dissolved Fe concentrations were lower than $0.5 \mu \mathrm{mol} \mathrm{l}^{-1}$. Concerning major elements, $\mathrm{Si} / \mathrm{Al}$ ratios increased with depth, from 6.5 at $2 \mathrm{~cm}$ to more than 9 at 38 cm depth (Fig. 2g). Concerning heavy metals in the dissolved phase, Cr concentrations were under the detection limit on the whole depth profile, while Ni concentrations increased with depth, being under the detection limit in the upper $5 \mathrm{~cm}$ and reaching $0.9 \mu \mathrm{mol} \mathrm{l}^{-1}$ between 30 and $35 \mathrm{~cm}$ depth (Tab. 3).

\subsection{Rhizophora stylosa forest}

Concerning the core collected beneath the Rhizophora stylosa forest, depth trends of the various parameters are presented in Fig. 3. Heavy metal concentrations ranged as follow (in $\mu \mathrm{mol} \mathrm{g}{ }^{-1}$ ): Fe from 400 to 720 ; Mn from 2.4 to 3.7; $\mathrm{Ni}$ from 0.9 to 2.4; Cr from 1.2 to 2; Zn from 0.1 to 2.1; Cu from 0.2 to 0.5 ; Co from 0.1 to 0.3 . Depth profiles were different for each metal, but there are some common trends for metals as $\mathrm{Cu}, \mathrm{Zn}$ and $\mathrm{Mn}$. The upper $20 \mathrm{~cm}$ of the core was enriched in organic carbon, with a mean TOC value close to $15 \%$, whereas below this depth TOC rapidly decreased to reach values close to $3 \%$. C/N values ranged between 20 and 30 on the whole depth profile without any specific trend (Fig. 3a). HI and OIRE6 values were stable with depth, with values close to $220 \mathrm{mg} \mathrm{HC} \mathrm{g}^{-1} \mathrm{TOC}$ and $90 \mathrm{mg} \mathrm{O}_{2} \mathrm{~g}^{-1}$ TOC, respectively (Fig. 3b). Suboxic conditions characterized the upper $6 \mathrm{~cm}$ of the core, with Eh values higher than $150 \mathrm{mV}$, TS concentrations lower $200 \mu \mathrm{mmol} \mathrm{g} \mathrm{g}^{-1}$ and dissolved Fe concentrations close to $10 \mu \mathrm{mol} \mathrm{l}^{-1}$. Below this depth, conditions became anoxic and sulfidic, with TS concentrations reaching $1300 \mu \mathrm{mol} \mathrm{g} \mathrm{g}^{-1}$ at $20 \mathrm{~cm}$ depth (Fig. 3e, f). Concerning major elements, Si/Al values increased with depth, from 3.58 to 7.42 (Fig. 3g). In the dissolved phase, Cr and Ni did not show any specific trend. Mean dissolved $\mathrm{Cr}$ and $\mathrm{Ni}$ concentrations were 0.2 and $0.3 \mu \mathrm{mol} \mathrm{l}^{-1}$, respectively (Tab. 3). 


\subsection{Dead Avicennia marina forest}

Concerning the core collected beneath the dead Avicennia marina forest, depth trends of the various parameters are presented in Fig. 4. Heavy metal concentrations ranged as follow (in $\mu \mathrm{mol} \mathrm{g}{ }^{-1}$ ): Fe from 63 to 530; Mn from 1.1 to 4.5; $\mathrm{Ni}$ from 0.1 to 3.6; Cr from 0.4 to 3.1; Zn from 0.7 to 1.7 ; Cu from 0.1 to 0.5; Co from 0.05 to 0.2. All heavy metals exhibited almost the same depth trend. Concentrations were highest at the top of the core, decreased to $35 \mathrm{~cm}$ depth, and then stabilized. TOC concentrations decreased on the whole depth profile, from 8 to $1 \%$ at 2 and $50 \mathrm{~cm}$ depth, respectively (Fig. 4a).

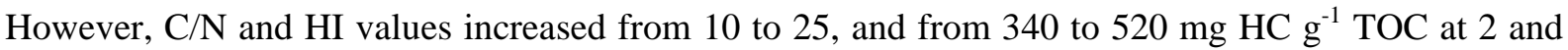
$35 \mathrm{~cm}$ depth, respectively. Below this depth, $\mathrm{C} / \mathrm{N}$ values decreased to 12 and $\mathrm{HI}$ values to $360 \mathrm{mg} \mathrm{HC}$ $\mathrm{g}^{-1}$ TOC (Fig. 4a, b). Anoxic conditions characterized the whole depth profile, with Eh values always lower than $0 \mathrm{mV}$ and dissolved Fe concentrations lower than $0.5 \mu \mathrm{mol} \mathrm{l}^{-1}$. However, TS concentrations ranged between 280 and $520 \mu \mathrm{mol} \mathrm{g}{ }^{-1}$ in the upper $35 \mathrm{~cm}$. Whereas below this depth, concentrations were close to $100 \mu \mathrm{mol} \mathrm{g}{ }^{-1}$. pH values slightly decreased with depth, from 7.4 to 6.7 at 2 and $50 \mathrm{~cm}$ depth, respectively (Fig. 4e, f). Concerning major elements, Si/Al values increased with depth, from 4.26 to 8.25 (Fig. 4g). Ni concentrations in the dissolved phase were under the detection limit, while Cr concentrations did not show any specific trend with depth, with a mean value close to $0.7 \mu \mathrm{mol} \mathrm{l}^{-1}$ (Tab. 3).

\subsection{Avicennia marina forest}

Concerning the core collected beneath the Avicennia marina forest, depth trends of the various parameters are presented in Fig. 5. Heavy metal concentrations ranged as follow (in $\mu$ mol g ${ }^{-1}$ ): Fe from 33 to 707 ; $\mathrm{Mn}$ from 2.2 to 4.7; Ni from 0.5 to 2.6; Cr from 0.5 to 2.1; Zn from 2 to 4; Cu from 0.2 to 0.4; Co from 0.1 to 0.4. Depth trends were different for each metal. Concerning the sedimentary organic content, two layers can be differentiated. In the upper $35 \mathrm{~cm}$, TOC values decreased from 13 to $8 \%$, while $\mathrm{C} / \mathrm{N}$ slightly increased from 15 to 25 (Fig. 5a). In this layer, HI values were stable and relatively high, close to $400 \mathrm{mg} \mathrm{HC} \mathrm{g}{ }^{-1}$ TOC, while OIRE6 were stable and low, close to $100 \mathrm{mg} \mathrm{O}_{2} \mathrm{~g}^{-}$ ${ }^{1}$ TOC (Fig. 5b). Below $35 \mathrm{~cm}$, TOC, C/N, and HI values strongly decreased to 1\%, 15, and $180 \mathrm{mg}$ 
HC $\mathrm{g}^{-1}$ TOC, respectively. $\mathrm{pH}$ values slightly increased from 5.4 to 6.4 at 4 and $50 \mathrm{~cm}$ depth, respectively. However, three layers of redox conditions can be differentiated. The sediment of the upper $15 \mathrm{~cm}$ was characterized by suboxic conditions with Eh values close to $200 \mathrm{mV}$, mean dissolved Fe concentration higher than $10 \mu \mathrm{mol} \mathrm{l}^{-1}$ and TS concentrations lower than $200 \mu \mathrm{mol} \mathrm{g}{ }^{-1}$. Between, 15 and $35 \mathrm{~cm}$ depth, TS concentrations strongly increased, reaching more than $800 \mu \mathrm{mol} \mathrm{g}{ }^{-1}$, while Eh values and dissolved Fe concentrations decreased to $-50 \mathrm{mV}$ and $0.9 \mu \mathrm{mol} \mathrm{l} \mathrm{l}^{-1}$, respectively, thus highlighting anoxic and sulfidic conditions. Below $35 \mathrm{~cm}$ depth, TS concentrations decreased to 300 $\mu \mathrm{mol} \mathrm{g}{ }^{-1}$, while dissolved Fe concentrations increased to $87 \mu \mathrm{mol} \mathrm{l}^{-1}$, thus highlighting again suboxic conditions (Fig. 5e, f). Concerning major elements, Si/Al ratios increased with depth, from 3.5 to more than 10 at $2 \mathrm{~cm}$ and $45 \mathrm{~cm}$ depth, respectively (Fig. $5 \mathrm{~g}$ ). $\mathrm{Cr}$ and $\mathrm{Ni}$ in the dissolved phase ranged from 0.21 to $0.46 \mu \mathrm{mol} \mathrm{l}^{-1}$, and from 0.19 to $1.88 \mu \mathrm{mol} \mathrm{l}^{-1}$, respectively, without any specific trend with depth (Tab. 3).

\section{Discussion}

\subsection{Mangrove zonation}

The existence of more or less different zones parallel to the coastline, each dominated by a different botanical species, is commonly observed in mangrove swamps throughout the world. However, the zonation of mangrove swamps often corresponds to a mosaic which varies according to the physical, biological and chemical interactions which become established between plant and substratum in a given zone. Salinity is recognized as a factor influencing the zonation of species in many places (Walsh, 1974). Flood tolerance (Naidoo, 1985; McKee, 1993) and altitude of ground surface (Baltzer, 1969) also indirectly control zonation, by controlling the immersion length and thus the evaporation and the salinity of pore-water. The specific properties of propagules also help explain many features of mangrove zonation (Rabinowitz, 1978; Smith et al., 1989). In our previous studies in French Guiana, we suggested that the predominant development of Avicennia germinans, which represent more than $90 \%$ of mangrove plants along this coastline, was probably due to the ability of its seedlings to take 
root into frequently reworked sediment (Marchand et al., 2004). Opposite to French Guiana, mangroves of New-Caledonia are composed of more than 20 species (Duke, 2006), Rhizophora spp. representing more than 50\% of mangrove areas, and Avicennia marina more than 15\% (Virly, 2006). As it is shown on Fig. 1, Avicennia develop at higher elevation than Rhizophora. In fact, Rhizophora develops mainly in zones daily swept by tides, the salinity of which is made homogeneous by the admixture of waters (Fig. 6). Avicennia trees develop in the borders of saltmarshes, and is thus less frequently immerged by tides, which induces higher pore-water salinities (Fig. 6). Consequently, Avicennia trees seem to be the best adapted to high situation in the intertidal zone, and to high porewater salinities. However, they develop at the price of an energy consumption which is incompatible with a certain growth. Avicennia rarely exceeds the shrub stage in New Caledonia. In our study site, a dead Avicennia area is present between the Rhizophora and the Avicennia stands. This dead area was situated at a lower elevation than the living forests at the time of the coring (Fig. 1), and sea water stayed in this area that was like a basin. The origin of this erosion process, which led to the lower elevation, is unknown.

We thus suggest that in New-Caledonia the main factor controlling the distribution of mangrove species is the soil salinity, which is strongly influence by the soil elevation. This distribution in the tidal area, by inducing differences in tidal immersion length, may be responsible for differences in sediment geochemistry between the study sites (see next chapters).

\subsection{Sediments characteristics}

The catchment of this bay is mainly composed of volcanic and sedimentary rocks rich in silicium, mainly sandstone. The name of the geological formation is "Formation des schistes de Pilou", it is of Senonian age (BRGM, 1965). Si/Al ratios are lower in the upper parts of the cores collected in mangrove sediments compare to the shoreface area and the bottom of the cores. This result indicate that the mineralogical composition of sediments is different between the upper and the deeper part of the core, the upper part being richer in clay, and the lower part in sand (Cojan and Renard, 1997; Duchauffour, 1997). This difference in mineralogical composition may induce differences in the 
geochemical processes in mangrove sediments between the upper and the deeper parts of the cores (see next chapters).

4.3 Mangrove stands and sedimentary organic matter composition

Mangrove forests are known to be highly productive ecosystems, with a net primary productivity estimated at $149 \mathrm{~mol} \mathrm{C} \mathrm{m} \mathrm{y}^{-1}$ (Bouillon et al., 2008). In addition, they can store large amounts of organic carbon in their substrate over several meters depth (Lallier-Vergès et al., 1998). The quantitatively most important source of organic carbon (OC) to mangrove sediments is litter from trees deposited at the sediment surface and subsurface root growth (Alongi, 1998). Nevertheless, epiphytic and benthic microalgae, macroalgae, and a mixture of riverine and marine material, more or less oxidized, can also contribute to sediment enrichment in OC (Marchand et al., 2003; Bouillon et al., 2004; Marchand et al., 2005). Mangrove sediments of Conception Bay are highly enriched in OC compared to the unvegetated shoreface sediment, with maximum values up to $18 \%$ and $3 \%$, respectively. Median total organic carbon (TOC) is of $2.2 \%$ in mangrove sediments, however, there are strong variations between sites, $44 \%$ of the available data having TOC less than $2 \%$ and $28 \%$ with values between 2 and 5\% (Kristensen et al., 2008). In Conception Bay, mean TOC value within mangrove sediments is around 9\%, which is relatively high, but close to the one measured by Alongi et al. (1998) in Malaysia for mangrove stands older than 15 years. In this study, beneath the Rhizophora stand, the organic content is higher than beneath the Avicennia stand, with TOC mean values in the upper $50 \mathrm{~cm}$ being $11.54 \%$ and $7.83 \%$, respectively. This can be the result of the more developed root-system of Rhizophora (Hesse, 1961), compared to the radial cable root system of Avicennia that develop only in the subsurface (deGranville, 1974). This may also explain that beneath Avicennia, TOC values higher than $10 \%$ are only observed in the upper $10 \mathrm{~cm}$ of the core, whereas beneath Rhizophora, they are observed down to $20 \mathrm{~cm}$ deep. In French Guiana, TOC depth trends beneath Avicennia stands were totally different, with a rapid decrease with depth, whatever the forest developmental stage, highlighting that the root-system actually develop in the subsurface (Marchand et al., 2003). The organic content was also lower as a result of the highly dynamic feature of the 
coastline, which induces a limited lifetime of the mangrove, and thus limited accumulation of OC (Marchand et al., 2003). Conversely, in New-Caledonia, mangroves have been stable for hundreds of years, allowing the accumulation of $\mathrm{OC}$ in their substrate. To identify the origin of the sedimentary organic pool, and its stage of decomposition, we used 3 proxies: $\mathrm{C} / \mathrm{N}$ ratios, hydrogen index (HI) and oxygen index (OIRE6) derived from Rock-Eval 6 pyrolysis. These parameters evidenced that algae derived OM was the main organic source in the upper $2 \mathrm{~cm}$ of the core collected in the unvegetated shoreface sediment, with a $\mathrm{C} / \mathrm{N}$ close to 7 , which is typical of this kind of material (Meyers and Lallier-Vergès, 1999). This layer was also characterized by low HI’s, indicating a rapid decomposition of this OM. An increase of TOC and C/N ratios below sediment surface indicates a mixing of higher plant and algae derived OM. Beneath both mangrove stands, C/N ratios varied between 15 and 35, reflecting the contribution of higher plant debris to the organic pool, and are in the range of ratios measured in mangrove sediments in Brazil (Lacerda et al., 1995), in India and Sri-Lanka (Bouillon et al., 2003). C/N ratios are higher beneath Rhizophora than beneath Avicennia probably resulting from three causes. First, C/N ratios of fresh tissues of Rhizophora are higher than those of Avicennia (Tab 4), e.g. 43 and 91 for their wood, respectively. Then, leaves are characterized by lower $\mathrm{C} / \mathrm{N}$ ratios than wood. Yet, Rhizophora stand develops on the sea-side of the mangrove, and is continuously subjected to tidal flushing, and thus leaf litter cannot accumulate compared to the Avicennia stand that develops on the land-side of the mangrove. On the field, leaf litter was observed beneath Avicennia and not beneath Rhizophora. Finally, beneath Avicennia stand, decomposition rate may be more efficient than beneath Rhizophora because of more oxic conditions (see next chapter; Alongi et al., 2000; Marchand et al., 2004). This result may indicate that beneath Rhizophora, the sedimentary organic pool derives mainly from woody tissues, whereas beneath Avicennia, the pool can be a mixture of decomposing leaves and wood. HI values depth trend confirm these hypothesis. Avicennia fresh leaves and wood have HI's of 569 and 405 mg HC g ${ }^{-1}$ TOC (Tab. 4), respectively, typical of fresh higher plant tissues. The fact that mangrove wood is characterized by slightly lowers HI's than leaves may be linked to a higher or even nearly exclusive ligno-cellulosic content (Marchand et al., 2005). OM decomposition induces its dehydrogenation, and thus a decrease of HI values, consequently in sediments, HI's are 
lower than in fresh tissues (Marchand et al., 2008). Beneath Avicennia, they are close to $400 \mathrm{mg} \mathrm{HC} \mathrm{g^{- }}$ ${ }^{1}$ TOC, highlighting a mixture of leaves and woody tissues. Conversely beneath Rhizophora, HI's were close to $200 \mathrm{mg} \mathrm{HC} \mathrm{g}^{-1}$ TOC. This result is consistent with the fact that beneath Rhizophora, OM mainly derived from woody tissues, since HI values of Rhizophora wood are low, around $300 \mathrm{mg}$ HC $\mathrm{g}^{-1}$ TOC, compared to the leaves, which have HI’s higher than $500 \mathrm{mg} \mathrm{HC} \mathrm{g}^{-1}$ TOC (Tab. 4).

In the core collected in the Avicennia forest, $\mathrm{C} / \mathrm{N}$ peaked at $35 \mathrm{~cm}$ depth, and at the same depth $\mathrm{HI}$ values decrease to $200 \mathrm{mg} \mathrm{HC} \mathrm{g}^{-1}$ TOC, which is the value measured beneath the Rhizophora forest. Actually, this result is consistent with our observations of the core since at this depth, the core was characterized by an increased proportion of red tissues, characteristic of Rhizophora wood. This result implies that the living Avicennia stand develop on sediments that were previously colonized by Rhizophora. This topic will be investigated in a further research effort concerning the evolution of the mangrove of New-Caledonia with climate change during the last millennium. Concerning OIRE6, values were relatively low, both beneath Avicennia and Rhizophora stands, close to $100 \mathrm{mg} \mathrm{O}_{2} \mathrm{~g}^{-1}$ TOC, which is characteristic of higher plant debris slightly oxidized. In French Guiana, OIRE6 values slightly increased, from 110 to $170 \mathrm{mg} \mathrm{O}_{2} \mathrm{~g}^{-1} \mathrm{TOC}$, in the upper $35 \mathrm{~cm}$ of a senescent forest, showing OM oxidation with decomposition (Marchand et al., 2008). Finally, beneath the Avicennia dead forest, depth trend are really specific. HI's are close to $400 \mathrm{mg} \mathrm{HC} \mathrm{g}^{-1} \mathrm{TOC}$ on the whole core, which is consistent with values measured beneath Avicennia living trees. However, TOC values are lower than 8, and decrease with increasing depth, while the $\mathrm{C} / \mathrm{N}$ ratios increased with depth. These results indicate a better preserved OM at depth, mainly derived from higher plant, while on the top of the core OM may derived both from higher plant and algae. This is consistent with the fact that no more fresh OM derived from higher plant is introduced into the sediment.

\subsection{Influence of mangrove stands on redox conditions, Fe and S cycling}

Although denitrification, manganese respiration and iron respiration are certainly underestimated, it is considered that aerobic respiration and sulfate reduction are the most important respiration processes in mangrove sediments (Alongi, 1998). In this present study, we thus decided to focus on Fe and S 
cycling, and also because trace metals can be incorporate into FeS (pyrite or greigite) during sulfatoreduction processes (Boulègue et al., 1982; Huerta-Diaz and Morse, 1992). Within Conception Bay, redox conditions, Fe and S concentrations, both in the solid and the dissolved phase, are highly variable between sampling sites and with depth. Suboxic to anoxic and sulphidic conditions were evidenced. Within the intertidal unvegetated area, a stratification of 3 distinctive layers can be identified: an anoxic and slightly sulfidic zone under a suboxic zone, and below an anoxic but nonsulphidic one. This intertidal area is situated at the lowest elevation of our sampling sites, and is thus more frequently inundated by tides, which may explain that atmospheric $\mathrm{O}_{2}$ did not penetrate deeply in the sediment. Aerobic degradation of labile materials near the surface is usually so rapid that $\mathrm{O}_{2}$ rarely penetrates more than $2 \mathrm{~mm}$ into the sediment (Kristensen et al., 1994). However, redox conditions can be fully oxic below totally anoxic conditions within the surficial mm of algal mats (De Witt et al., 1989). When $\mathrm{O}_{2}$ is consumed, $\mathrm{OM}$ is oxidized by a wide variety of anaerobic microorganisms using electron acceptors in the following sequence according to the energy yield: $\mathrm{Mn}^{4+}, \mathrm{NO}_{3}{ }^{-}, \mathrm{Fe}^{3+}$ and $\mathrm{SO}_{4}{ }^{2-}$ . In the upper $6 \mathrm{~cm}$ of the core, the reduction of $\mathrm{SO}_{4}{ }^{2-}$ was not reached probably because of the low organic content, the proximity of the surface, and possible infaunal burrowing. While below, the anoxic and sulphidic layer, with TS up to $300 \mu \mathrm{mol} \mathrm{g}{ }^{-1} \mathrm{dw}$, can be clearly associated with an increase of organic content, to more than 3\% compared to the mean TOC value of the core, which is lower than 1\%. The fact that below this layer, the sediment was anoxic but non-sulphidic may be linked to the lower OC content, which may be also less metabolizable as highlighted by the higher OIRE6 values. In addition, the fact that $\mathrm{Si} / \mathrm{Al}$ ratios increased at depth may indicate a sandier feature of the sediment, and thus the fact that sediments may allow more lateral exchange. Thus, without vegetation, redox conditions within intertidal sediments seem to be mainly controlled by organic content, but also by depth. In mangrove sediments, redox conditions are dependent on the quantity and reactivity of organic matter, sediment grain size, bioturbation activity, like in marine sediments, but also on forest age, physiological activities of the root system, extent of water logging and crabs burrowing (Clark et al., 1998; Kristensen, 2000; Marchand et al., 2004; Marchand et al., 2006; Kristensen et al., 2008). Within mangrove sediments of Conception Bay, with the organic enrichment of sediment described 
previously, resulting from plant development, one can imagine that redox conditions will be anoxic and sulphidic really close to sediment surface, but it is not the case. Beneath Rhizophora stand, suboxic conditions prevailed in the upper $5 \mathrm{~cm}$, while the OC content is the highest. Below this depth, the sediment became anoxic and sulphidic. The suboxic condition may be explained by biological or physical factors. First, crab burrows may induce such condition, by allowing the renewal of electron acceptors during high tide. However this mangrove that is situated in an urban area is very poor in crabs. Bioturbation can also be created by the root system of Rhizophora, however it is known that this root system develop deeper than $5 \mathrm{~cm}$. The roots of Rhizophora are at their most dense between 15 and $30 \mathrm{~cm}$ depth (Otero et al., 2006). In addition, Rhizophora root system is not known to diffuse $\mathrm{O}_{2}$ into the sediment. We suggest that the suboxic conditions that prevailed in the upper sediment beneath the Rhizophora stand result from the fact that this mangrove develop at higher physiographic conditions, is thus less inundated by tides, and as a consequence exchange between atmosphere and sediment can be more efficient than in the unvegetated sediment. Below this suboxic layer, the lowest Eh and the highest TS concentrations were measured probably as a result of the high organic content. Since Hesse (1961), Rhizophora sediments are known to be highly sulphidic due to the fibrous and organic nature of its sediment. Consequently, the length of waterlogging of a mangrove stand, depending on its topographic situation in the intertidal zone, seems to be also a main factor controlling redox conditions. Opposite to Rhizophora sediments, in which TS increased from the top of the core to $20 \mathrm{~cm}$ depth, Avicennia sediments show suboxic to oxic conditions in the upper $15 \mathrm{~cm}$, and only below this depth TS started to increase. Avicennia trees are known for their extensive cable root system developing close to sediment surface (deGranville, 1974). Otero et al. (2006) also demonstrated that their root system is concentrated in the upper $20 \mathrm{~cm}$. Since Scholander et al. (1955), it is known that pneumatophores constitute a pathway for the exchange of oxygen between atmosphere and sediments. In addition, this cable root system has the capacity to diffuse oxygen into the sediment, creating oxidized rhizosphere (Thibodeau and Nickerson, 1986). In French Guiana, we demonstrated that the older the Avicennia forest, the higher the redox values, providing the sedimentary organic content was low, highlighting the key role of root growth on redox conditions (Marchand et al, 2003; 
2004). In New-Caledonia, Avicennia marina develop behind Rhizophora spp., which colonize the seashore, and thus Avicennia develop at a higher elevation than Rhizophora (Fig. 1). As a consequence, sediments beneath Avicennia are less frequently inundated by tides, and exchange with atmosphere and sediment dessication can add their effect to the diffusion of oxygen via the root system. Between, 15 and $35 \mathrm{~cm}$ depth, below the living roots layer, redox conditions were anoxic and sulphidic, probably as a result of the high organic content. Below $40 \mathrm{~cm}$ depth, redox conditions

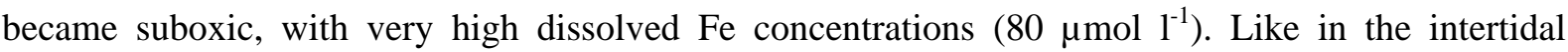
unvegetated sediment, the fact that this layer is less enriched in OC, that this OC is less metabolizable, as highlighted by the higher OIRE6, and that the $\mathrm{Si} / \mathrm{Al}$ ratios indicated a sandier nature of the sediment, may explain these conditions. The role of the Avicennia root system in creating suboxic to oxic conditions in the upper sediment is also evidenced when having a look on the depth trend of the various parameters in the Avicennia dead forest. This dead forest develops at almost the same physiographic conditions than the living one, and the organic content is lower. Consequently, if waterlogging length would be the main factor controlling redox conditions, suboxic conditions should also prevail in the upper core. However the whole depth profile is anoxic, indicating that living Avicennia root system has a key role on the redox conditions of the upper sediments. In French Guiana, we also demonstrated that the redox conditions vary considerably between the dry and the rainy season, the water table being higher during the rainy season inducing anoxic conditions. In the present study, we only performed core during the dry season, but we are aware that results may be different during the rainy season (Marchand et al., 2004).

\subsection{Distribution of heavy metals in mangrove sediments and pore-water}

Heavy metal concentrations, in mangrove sediments, are usually quite high (Lacerda et al., 1988; Tam and Wong, 2000). On the one hand, this richness can derive from anthropogenic metal loadings carried by the upstream of tributary rivers. Many authors described high heavy metals concentrations in mangrove sediments as a result of anthropogenic input, proximity to harbor, landfill, industrial area, etc (Clark et al., 1998; Machado et al, 2002). On the other hand, this richness may result from 
mangrove physico-chemical properties, e.g. efficiency to trap material from the water column, richness in OM, richness in clay, etc. Ray et al. (2006) observed that metal concentrations were higher in mangrove sediments compared to adjacent estuarine sediments, mainly as a result of higher organic content. Conversely, in French Guiana, concentrations in mangrove sediments and in unvegetated coastal sediment were similar, as a result of the dynamic feature of the coastline and the occurrence of oxic to suboxic processes in the earlier stages of mangrove development (Marchand et al., 2006). Nevertheless and despite the fact that no anthropogenic sources were identified, these sediments were also relatively rich in some metals, notably $\mathrm{Hg}$, and this as a result of the nature of the Amazon watershed (Roulet et al., 1996, 2000). In New-Caledonia, highly weathered Ferralsols, enriched in heavy metals, occur extensively, deriving from ultramafic rocks and representing a third of the surface of the main island (Trescases, 1973; Lathal, 1985). In the present study, we were interested in determining concentrations and distribution of heavy metals in a mangrove developing downstream a watershed that is not enriched in heavy metals, in order to have some baseline data for further study. In fact, Fe, Zn, Mn, Co concentrations were lower than in the mangroves previously cited. Nevertheless, mean Ni concentration was close to $1.11 \mu \mathrm{mol} \mathrm{g}^{-1}$ (Tab. 1), which is twice the concentrations we measured in French Guiana $\left(0.54 \mu \mathrm{mol} \mathrm{g}{ }^{-1}\right)$, and also higher than those measured in Hong Kong (Tam and Wong, 2000), and in Colombia (Perdomo et al., 1998), where anthropogenic sources were identified. This result suggest that even if the catchment of the present study is not enriched in $\mathrm{Ni}$, coastal sediments of the lagoon present relatively high Ni concentrations, probably as a result of the current that bring sediments originated from lateritic watershed. Fernandez et al. (2006) highlighted that natural and mining-related terrigenous inputs delivered to the lagoon by the small Coulée River catchment, composed of ultramafic rocks (BRGM, 1975), and which is close to our study site, are not limited to the closest bay, but partly exported mainly as a result of prevailing along-shore currents generated by the trade winds.

Heavy metals concentrations varied greatly between sampling sites and with depth. Many parameters may influence the distribution of heavy metals in mangrove sediments, among which the quality and quantity of sedimentary organic matter, and the redox driven Fe, S cycling. Beneath the dead 
Avicennia forest and in the unvegetated sediments, heavy metals behaviors seem to be similar regarding the relationships with TOC. The cores collected within these study sites present clear heavy metals distribution, having all the same depth trend. The higher the organic content, the higher the metal concentrations. The dead forest, richer in OM, is also richer in heavy metals, highlighting the role of OM in metal accumulation in estuarine sediments. Taking into account its high specific surface area, OM can form complexes with heavy metals (Nissenbaum and Swain, 1976). In fact, $\mathrm{Cr}, \mathrm{Cu}$, and Ni are correlated with TOC (Tab. 5), as observed by Chen et al. (2007) in Taiwan estuarine sediments, and by Ray et al. (2006) in Indian mangrove sediments. The top of the core presents the highest concentrations of the whole samples set, with Ni concentration higher than $3 \mu \mathrm{mol} \mathrm{g}{ }^{-1}$. Nevertheless, heavy metals are probably not only associated with OM. Within these sites, the higher the organic content, the higher the sulphur content, resulting from the precipitation of sulphur during processes of sulfato-reduction induced by OM decomposition. In anoxic conditions, heavy metals can precipitate with sulphide minerals, and being rapidly removed from the dissolved phase (Huerta-Diaz and Morse, 1992; Aragon and Miguens, 2001). These sulphide minerals are probably iron sulphide ones, like pyrite or greygite, as highlighted by the correlation between TS and Fe concentrations (Tab. 5). At the bottom of the core collected in the unvegetated sediments, concentrations in OC were lower, conditions were less anoxic and the $\mathrm{pH}$ slightly less basic. At this level, Ni concentration in the dissolved phase increased to $0.91 \mu \mathrm{mol} \mathrm{g}{ }^{-1}$, probably as a result of their release in pore-water during sulphide oxidation, which may indicate that part of $\mathrm{Ni}$ was, actually, associated with sulphide. Burton et al. (2006) observed that nickel extractability was low, possibly due to formation of pure $\mathrm{Ni}-\mathrm{S}$ phases or sequestration by pyrite Consequently, within these sediments, in which oxygen supply only comes from the surface, OM richness is the main factor driving, first, the precipitation of sulphur via sulfato-reduction processes, and then, the concentrations of heavy metals, which may be associated both with OM or sulphur minerals. In Brazilian mangrove sediments, OM and sulphide seem to be the most important factors regulating the amount of free or biologically available metals (Kehrig et al., 2003). Beneath Rhizophora stand, despite a higher organic content, as well as higher sulphur content, heavy metals concentrations were not higher than those measured in the sediment collected beneath 
the dead forest. In addition, no specific trend can be observed with depth except for $\mathrm{Cu}, \mathrm{Zn}$ and $\mathrm{Mn}$. Solid Fe concentrations depth trend follow the one of TS, probably highlighting the precipitation of iron sulphides (Berner, 1984), while Mn concentrations reached their maximum values at the bottom of the core. Mn depth trends are not correlated with TS ones since Mn sulphides are not stable, and in anoxic conditions Mn precipitate mostly as carbonate minerals such as rhodochrosite (Aller et al., 2004). In previous studies (Marchand et al., 2006; 2008), we suggested that the decomposition of OM in upper mangrove sediments leads to the production of DIC that can migrate to deeper layers with the percolation of pore-water, where carbonates can precipitate because of the marked anoxic conditions prevailing there. The higher the organic content in the suboxic upper layer, the higher the carbonate concentrations in the bottom anoxic layer. The fact that there are no specific trend with depth for most metals may be related to the fact that redox conditions are highly variable, conversely to the stable anoxic conditions of the dead forest and the unvegetated sediments, and that when sulphides minerals are dissolved in suboxic conditions, they can be incorporated into oxyhydroxide that precipitate in micro-oxic environment (Atkinson et al, 2007; Fereira et al., 2007). Either iron sulphide or iron oxide are believed to provide good adsorbing sites for heavy metals (Lee, 2006), explaining the low concentrations measured in pore-water. In Brazilian mangrove swamps, Otero et al. (2009) observed that there was a significant decrease with depth in all the types of Fe oxyhydroxides measured, particularly the poorly crystalline forms, in relationship with the decreasing Eh values. We suggest that these oxyhydoxides may be a sink for trace metals in the upper core of our studied mangrove. Beneath Avicennia trees, the scenario is very similar except that oxic to suboxic conditions prevail to $15 \mathrm{~cm}$ depth due to the cable root system that diffuses oxygen in the upper sediment. These conditions probably induced some sulphide minerals dissolution and thus the release of heavy metals in porewater. The fact that Fe concentrations in pore water is relatively low, probably results to its rapid precipitation as oxyhydoxides. In fact, the upper sediment beneath Avicennia is characterized by the highest $\mathrm{Ni}$ concentration in the dissolved phase, up to $1.88 \mu \mathrm{mol} \mathrm{l}^{-1}$. This result suggest that because of the specificity of the Avicennia root system, heavy metals in the dissolved phase present higher concentrations than beneath Rhizophora stand, and thus that heavy metals are more bioavailable and 
potentially more mobile beneath Avicennia stand. This specificity enhances the potential of some metals entering into the food chain beneath Avicennia. Nevertheless, during the rainy season, with a higher water table, results may have been different. In a previous study, we suggested that beneath Avicennia, metals precipitated with sulphides during the rainy season due the anoxic conditions prevailing, and resulting from the higher water table (Marchand et al., 2006).

\section{Conclusions}

This preliminary study, in the mangroves of New-Caledonia, allowed us to better understand heavy metal distribution in relationship with OM cycling and mangrove zonation, in a coastal area that is not affected by mining activities. The conclusion can be summarized as follow :

- Organic content is higher beneath the Rhizophora stand than beneath the Avicennia stand. We suggest that this can result from the more developed root-system of Rhizophora compared to the radial cable root system of Avicennia that develop only in the subsurface. The difference of extension of their root system may also explain that the OC enrichment is deeper beneath Rhizophora than Avicennia.

- Surprisingly at depth, beneath Avicennia, the sediment was characterized by an increased proportion of Rhizophora tissues. This result implies that the living Avicennia stand develop on sediments that were previously colonized by Rhizophora. This topic will be investigated in a further research effort concerning the evolution of the mangrove of New-Caledonia with climate change during the last millennium.

- Organic sources also differ beneath the two species, and as a result of their distribution. Beneath Rhizophora, the sedimentary organic pool derives mainly from woody tissues, whereas beneath Avicennia, the pool can be a mixture of decomposing leaves and wood. Actually, Rhizophora stand develops on the sea-side of the mangrove, and is continuously subjected to tidal flushing, and thus leaf litter cannot accumulate compared to the Avicennia stand that develops on the land-side of the mangrove. 
- Mangrove zonation also induces differences in the redox conditions that occurred beneath the 2 species. We suggest that the suboxic conditions that prevailed in the upper sediment beneath the Rhizophora stand result from air diffusion from the atmosphere. This layer is not very deep because Rhizophora stand is frequently submerged by tides. Below this layer, and as a result of the high organic content, the conditions were anoxic and sulfidic. Conversely beneath Avicennia, suboxic conditions prevailed deeper. We suggest that oxygen diffusion from atmosphere is more important because of its higher position in the intertidal zone, and that this diffusion add its effect to the one via the root system, which is well known to create oxidized rhizosphere. Consequently, the present study confirms that the length of waterlogging of a mangrove stand, depending on its topographic situation in the intertidal zone, seems to be a main factor controlling redox conditions in the upper sediment, as well as the activity of the root system.

- Despite its high organic content, mangrove swamps of Conception Bay are not enriched in heavy metals, except Ni. We suggest that even if the catchment of the present study is not enriched in $\mathrm{Ni}$, coastal sediments of the bay present relatively high Ni concentrations, probably as a result of the current that bring sediments originated from lateritic watershed.

- Heavy metals distribution within sediments and pore-water appear to result from diagenetic processes linked to OM decomposition. Beneath the dead Avicennia forest and in the unvegetated sediments, the higher the organic content, the higher the metal accumulation. The dead forest, richer in $\mathrm{OM}$, is also richer in heavy metals, highlighting the role of $\mathrm{OM}$ in metal accumulation in estuarine sediments. Nevertheless, the higher the organic content, the higher the sulphur content too. As a consequence, with our data set, it is not possible to decipher between heavy metals complexation with humic acids or incorporation into sulphide minerals. Beneath living mangrove stand, despite a higher organic content, as well as higher sulphur content, heavy metals concentrations were not higher than those measured in the sediment collected beneath the dead forest. In addition, no specific trend were evidenced, probably resulting from the fact that when sulphides minerals are dissolved in suboxic conditions of the upper layers, they can be incorporated into oxyhydroxides that precipitate in microoxic environment. 
- Concerning heavy metals in the dissolved phase, the higher concentrations were measured in the upper suboxic conditions of the Avicennia forets. We suggest that because of the specificity of the Avicennia root system and its position in the intertidal zone, heavy metals in the dissolved phase present higher concentrations than beneath Rhizophora stand, and thus that heavy metals are more bioavailable and potentially more mobile beneath Avicennia stand. This specificity enhances the potential of some metals entering into the food chain beneath Avicennia.

Now that we have some baseline information on heavy metals dynamics, we will work on this topic in mangrove that are situated downstream ultramafic soils, which are exploited or not, in order to assess the impact of extracting activities on the concentration and distribution of heavy metals in mangroves.

\section{Acknowledgments}

The authors would like to thank Thierry Hoibian (University of New-Caledonia) for his valuable assistance in the field. The help of Patrick Baillif and Marielle Hatton for their technical assistance is also gratefully acknowledged. Reviewers comments were very appreciated.

\section{References}

Aller, R.C., Heilbrun, C., Panzeca, C., Zhu, Z., Baltzer, F., 2004. Coupling between sedimentary dynamics, early diagenetic processes, and biogeochemical cycling in the Amazon-Guianas mobile mud belt: coastal French Guiana. Mar. Geol. 208, 331-360.

Alongi, D.M., 1998. Coastal Ecosystem Processes. CRC Press, p. 419.

Alongi, D.M., Sasekumar, A., Tirendi, F., Dixon, P., 1998. The influence of stand age on benthic decomposition and recycling of organic matter in managed mangrove forests of Malaysia. J. Exp. Mar. Biol. Ecol. 225, 197-218.

Alongi, D.M., Tirendi, F., Clough, B.F., 2000. Below-ground decomposition of organic matter in forests of the mangrove Rhizophora stylosa and Avicennia marina along the arid coast of Western Australia. Aquat. Bot. 68, 97-122.

Aragon, G., Miguens, F., 2001. Microscopic analysis of pyrite in the sediments of two Brazilian mangrove ecosystems. Geo Mar. Lett. 21, 157- 161. 
Atkinson, C.A., Jolley, D.F., Simpson, S.L., 2007. Effect of overlying water pH, dissolved oxygen, salinity and sediment disturbances on metal release and sequestration from metal contaminated marine sediments. Chemosphere 69( 9), 1428-1437

Baltzer, F., 1969. Les formations végétales associées au delta de la Dumbea (Nouvelle-Calédonie) et leurs indications écologiques, géomorphologiques et sédimentologiques mises en évidence par la cartographie. Cah. ORSTOM, Ser. Géol. I, I, 59-84.

Berner, R. A., 1984. Sedimentary pyrite formation: an update. Geochim. Cosmochim. Acta 48, 605615.

Bouillon, S., Dahdouh-Guebas, F., Rao, A.V.V.S., Koedam, N., Dehairs, F., 2003. Sources of organic carbon in mangrove sediments: variability and possible ecological implications. Hydrobiologia 495, 33-39.

Bouillon, S., Moens, T., Overmeer, I., Koedam, N., Dehairs, F., 2004. Resource utilization patterns of epifauna from mangrove forests with contrasting inputs of local versus imported organic matter. Mar. Ecol. Prog. Ser. 278, 77-88.

Bouillon, S., Borges, A.V., Castañeda-Moya, E., Diele, K., Dittmar, T., Duke, N.C., Kristensen, E., Lee, S.Y., Marchand, C., Middelburg, J.J., Rivera-Monroy, V.H., Smith III, T.J., Twilley, R.R., 2008. Mangrove production and carbon sinks: a revision of global budget estimates. Global Biogeochem. Cycling 22, GB2013.

Boulègue, J., Lord, C.J. III, Church, T.M., 1982. Sulfur speciation and associated trace metals (Fe, Cu) in the porewaters of Great Marsh, Delaware. Geochim. Cosmochim. Acta 46, 453-464.

BRGM, 1965. Geological map of Nouméa, feuille SF-58-XVII-1b.

BRGM, 1975. Geological map of St. Louis, feuille SF-58-XVII-2a.

Burton, E.D., Bush, R.T., Sullivan, L.A., 2006. Fractionation and extractability of sulfur, iron and trace elements in sulfidic sediments. Chemosphere 64, 1421-1428.

Chen, C.-W., Kao, C.-M., Chen, C.-F., Dong, C.-D., 2007. Distribution and accumulation of heavy metals in the sediments of Kaohsiung Harbor, Taiwan. Chemosphere 66, 1431-1440.

Clark, M.W., McConchie, D., Lewis, D.W., Saenger, P., 1998. Redox stratification and heavy metal partitioning in Avicennia-dominated mangrove sediments: a geochemical model. Chem. Geol. 149, 147-171.

Cojan, I., Renard, M. 1997. Sedimentologie. Ed. Masson. Paris. 418pp.

De Wit, R., Jonkers, H.M., Van den Ende, F.P., Van Gemerden, H., 1989. In situ fluctuations of oxygen and sulphide in marine microbial sediment ecosystems. J. Sea Res. 23, 271-281.

de Granville, J.J., 1974. Aperçu sur la structure des pneumatophores de deux espèces des sols hydromorphes en Guyane. Cah. ORSTOM, Sér. BD 23, 3-22.

Duke, N.C., 2006. Mangrove biodiversity in New-Caledonia. In «Typologies et Biodiversité des mangroves de Nouvelle-Calédonie». ZoNéCo program report, pp. 213. 
Duke, N.C., Meynecke, J.-O., Dittmann, S., Ellison, A.M., Anger, K., Berger U., Cannicci, S., Diele, K., Ewel, K. C., Field, C. D., Koedam, N., Lee, S. Y., Marchand C., Nordhaus, I., Smith III, T. J., Dahdouh-Guebas, F. 2007. A world without mangroves? Science 317, 41-42.

FAO, 2003. Status and trends in mangrove area extent worldwide. Forest Resources Division, FAO, Paris.

Ferreira, T.O., Otero, X.L., Vidal-Torrado, P., Macías, F., 2007. Effects of bioturbation by root and crab activity on iron and sulfur biogeochemistry in mangrove substrate. Geoderma 142, 36-46.

Fernandez, J.-M., Ouillon, S., Chevillon, C., Douillet, P., Fichez, R., Le Gendre, R., 2006. A combined modelling and geochemical study of the fate of terrigenous inputs from mixed natural and mining sources in a coral reef lagoon (New Caledonia). Mar. Pollut. Bull. 52, 320-331.

Furukawa, K.,Wolanski, E., Mueller, H., 1997. Currents and sediment transport in mangrove forests. Estuar. Coast. Shelf Sci. 44, 301-310.

Harbison, P., 1986. Mangrove muds: a sink and a source for trace metals. Mar. Pollut. Bull. 17, 246250.

Hesse, P.R., 1961. Some differences between the soils of Rhizophora and Avicennia mangrove swamp in Sierra Leone. Plant Soil 14, 335- 346.

Huerta-Diaz, M.A., Morse, J.W., 1992. Pyritization of trace metals in anoxic marine sediments. Geochim. Cosmochim. Acta 56, 2681-2702.

Kehrig, H.A., Pinto, F.N., Moreira, I., Malm, O., 2003. Heavy metals and methylmercury in a tropical coastal estuary and a mangrove in Brazil. Org. Geochem. 34, 661-669.

Kristensen, E., Bouillon, S., Dittmar, T., Marchand, C., 2008. Organic carbon dynamics in mangrove ecosystem. Aquat. Bot. 89 (2), 210-219.

Kristensen, E., King, G.M., Holmer, M., Banta, G.T., Jensen, M.H., Hansen, K., Bussarawit, N., 1994. Sulfate reduction, acetate turnover and carbon metabolism in sediments of the Ao-Nam-Bor mangrove, Phuket, Thailand. Mar. Ecol. Prog. Ser. 109, 245-255.

Kristensen, E., 2000. Organic matter diagenesis at the oxic/anoxic interface in coastal marine sediments, with emphasis on the role of burrowing animals. Hydrobiologia 426, 1-24.

Lacerda, L.D., Martinelli, L.A., Rezende, C.A., Mozetto, A.A., Ovalle, A.R.C., Victoria, R.I., Silva, C.A.R., Nogueira, F.B., 1988. The fate of heavy metals in suspended matter in a mangrove creek during a tidal cycle. Sci. Total Environ. 75, 249-259.

Lacerda, L.D., Ittekkot, V., Patchineelam, S.R., 1995. Biogeochemistry of mangrove soil organic matter: a comparison between Rhizophora and Avicennia soils in south-eastern Brazil. Estuar. Coast. Shelf Sci. 40, 713-720.

Lafargue, E., Marquis, F., Pillot, D., 1998. Rock-Eval 6 applications in hydrocarbon exploration, production and soil contamination studies. Revue de l'Institut Français du Pétrole 53, 421-437. 
Lallier-Vergès, E., Perrussel, B.P., Disnar, J.-R., Baltzer, F., 1998. The relationship between environmental conditions and the diagenetic evolution of organic matter derived from higher plant in a present mangrove swamp system (Guadeloupe, French West Indies). Org. Geochem. 29, 1663-1686.

Lathal, M., 1985. Altération et pédogenèse sur roches ultrabasiques en Nouvelle-Calédonie. Ph.D. Thesis, University of Dijon, 331 pp.

Lee, S., 2006. Geochemistry and partitioning of trace metals in paddy soils affected by metal mine tailings in Korea. Geoderma 135, 26-37

Machado, W., Moscatelli, M., Rezende, L.G., Lacerda, L.D., 2002. Mercury, zinc, copper accumulation in mangrove sediments surrounding a large landfill in southeast Brazil. Environ. Pollut. 120, 455- 461.

Marchand, C., Lallier-Vergès, E., Baltzer, F., 2003. The composition of sedimentary organic matter in relation to the dynamic features of a mangrove-fringed coast in French Guiana. Estuar. Coast. Shelf Sci. 56, 119-130.

Marchand, C., Baltzer, F., Lallier-Vergès, E., Albéric, P., 2004. Pore-water chemistry in mangrove sediments in relationship to species composition and developmental stage (French Guiana). Mar. Geol. 208, 361-381.

Marchand, C., Disnar, J.-R., Lallier-Vergès, E., Lottier, N., 2005. Early diagenesis of carbohydrates and lignin in mangrove sediments subject to variable redox conditions (French Guiana). Geochim. Cosmochim. Acta 69, 131-142.

Marchand, C., Lallier-Vergès, E., Baltzer, F., Albéric, P., Cossa, D., Baillif, P., 2006. Heavy metals distribution in mangrove sediments along the mobile coastline of French Guiana. Mar. Chem. 98, $1-17$.

Marchand, C., Lallier-Vergès, E., Disnar, J.-R., Kéravis, D., 2008. Organic carbon sources and transformations in mangrove sediments: a Rock-Eval pyrolysis approach. Org. Geochem. 39, 408-421.

Duchauffour, P. 1997. Abrégé de pédologie, $5^{\text {ème }}$ édition. Ed. Masson. Paris. 291 pp.

McKee, K.L., 1993. Soil physicochemical patterns and mangrove species distribution—reciprocal effects? J. Ecol. 81, 477-487.

Meyers, P. A., Lallier-Vergès, E., 1999. Lacustrine sedimentary organic matter records of Late Quaternary paleoclimates. J. Paleolimnol. 21, 345-372.

Nagelkerken, I., Blaber, S.J.M., Bouillon, S., Green, P., Haywood, M., Kirton, L.G., Meynecke, J.-O., Pawlik, J., Penrose, H.M., Sasekumar, A., Somerfield, P.J., 2008. The habitat function of mangroves for terrestrial and marine fauna: A review. Aquat. Bot. 89, 155-185.

Naidoo, G., 1985. Effect of waterlogging and salinity on plant- water relations and on the accumulation of solutes in three mangrove species. Aquat. Bot. 22, 133-143. 
Nissenbaum, A., Swaine, D.J., 1976. Organic-metal interactions in recent sediments: the role of humic substances. Geochim. Cosmochim. Acta 40, 809-816.

Otero, X.L., Ferreira, T.O., Vidal-Torrado, P., Macías, F., 2006. Spatial variation in pore water geochemistry in a mangrove system (Pai Matos island, Cananeia-Brazil). Applied Geochem. 21, 2171-2186.

Otero, X.L., Ferreira, T.O., Huerta-Díaz, M.A., Partiti, C.S.M., Souza Jr., V., Vidal-Torrado, P., Macías, F., 2009. Geochemistry of iron and manganese in soils and sediments of a mangrove system, Island of Pai Matos (Cananeia — SP, Brazil). Geoderma 148, 318-335.

Perdomo, L., Ensminger, I., Espinosa, L.F., Elster, C., Wallner-Kersanach, M., Schnetter, M.-L., 1998. The mangrove ecosystem of the Ciénaga Grande de Santa Marta (Colombia): Observations on regeneration and trace metals in sediment. Mar. Pollut. Bull. 37 (8-12), 393-403.

Rabinowitz, D., 1978. Dispersal properties of mangrove propagules. Biotropica 10, 47-57.

Ramos e Silva, C.A., da Silva, A.P., de Oliveira, S.R., 2006. Concentration, stock and transport rate of heavy metals in a tropical red mangrove, Natal, Brazil. Mar. Chem. 99, 2-11.

Ray, A.K., Tripathy, S.C., Patra, S., Sarma, V.V., 2006. Assessment of Godavari estuarine mangrove ecosystem through trace metal studies. Environment International 32, 219 - 223.

Roulet, M., Lucotte, M., Rheault, I., Tran, S., Farella, N., Canuel, R., Mergler, D., Amorim, M., 1996. Mercury in Amazonian soils: accumulation and release. Proceedings of the 4th International Symposium on the Geochemistry of the Earth Surface, 22-28 July, Ilkey, UK. , pp. 453- 457.

Roulet, M., Lucotte, M., Canuel, R., Farella, N., Courcelles, M., Guimaraes, J.R.D., Mergler, D., Amorin, M., 2000. Increase in Mercury contamination recorded in lacustrine sediments following deforestation in the central Amazon. Chem. Geol. 165, 243- 266.

Scholander, P.F., Van dam, L., Scholander, S.I., 1955. Gas exchange in the roots of mangrove. Am. J. Bot. 42, 92-98.

Smith, T.J., Chan, H.T., McIvor, C.C., Robblee, M.B., 1989. Comparison of seed predation in tropical tidal forests from three continents. Ecology 70, 146-151.

Song, J., Luo, Y.M., Zhao, Q.G., Christie, P., 2003. Novel use of soil moisture samplers for studies on anaerobic ammonium fluxes across lake sediment-water interfaces. Chemosphere 50, 711-715.

Spalding, M.D., Blasco, F., Field, C.D., 1997. World Mangrove Atlas. International Society for Mangrove Ecosystems, Okinawa, Japan.

Tam, N.F.Y., Wong, Y.S., 2000. Spatial variation of heavy metal in surface sediments of Hong Kong mangrove swamps. Environ. Pollut. 110, 195-205.

Thibodeau, F.R., Nickerson, N.H., 1986. Differential oxidation of mangrove substrate by Avicenia germinans and Rhizophora mangle. Am. J. of Bot. 73(4), 512-516.

Tomlinson, P. B. 1986. The Botany of Mangroves (Cambridge University Press, Cambridge), pp. 413. 
Trescases, J.J., 1973. L'évolution géochimique supergène des roches ultrabasiques en zone tropicale.

Formation des gisements nickélifères de Nouvelle-Calédonie. Ph.D. Thesis OA 8708, Université Louis Pasteur, Strasbourg.

Virly, S, 2006. Atlas des mangroves de Nouvelle-Calédonie. In «Typologies et Biodiversité des mangroves de Nouvelle-Calédonie». ZoNéCo program report, pp. 213.

Walsh, G.E., 1974. Mangroves, a review. In: Reimold, R.J., Queens, W.H. (Eds.), Ecology of Halophytes. Academic Press, pp. 51- 174. 
Figures

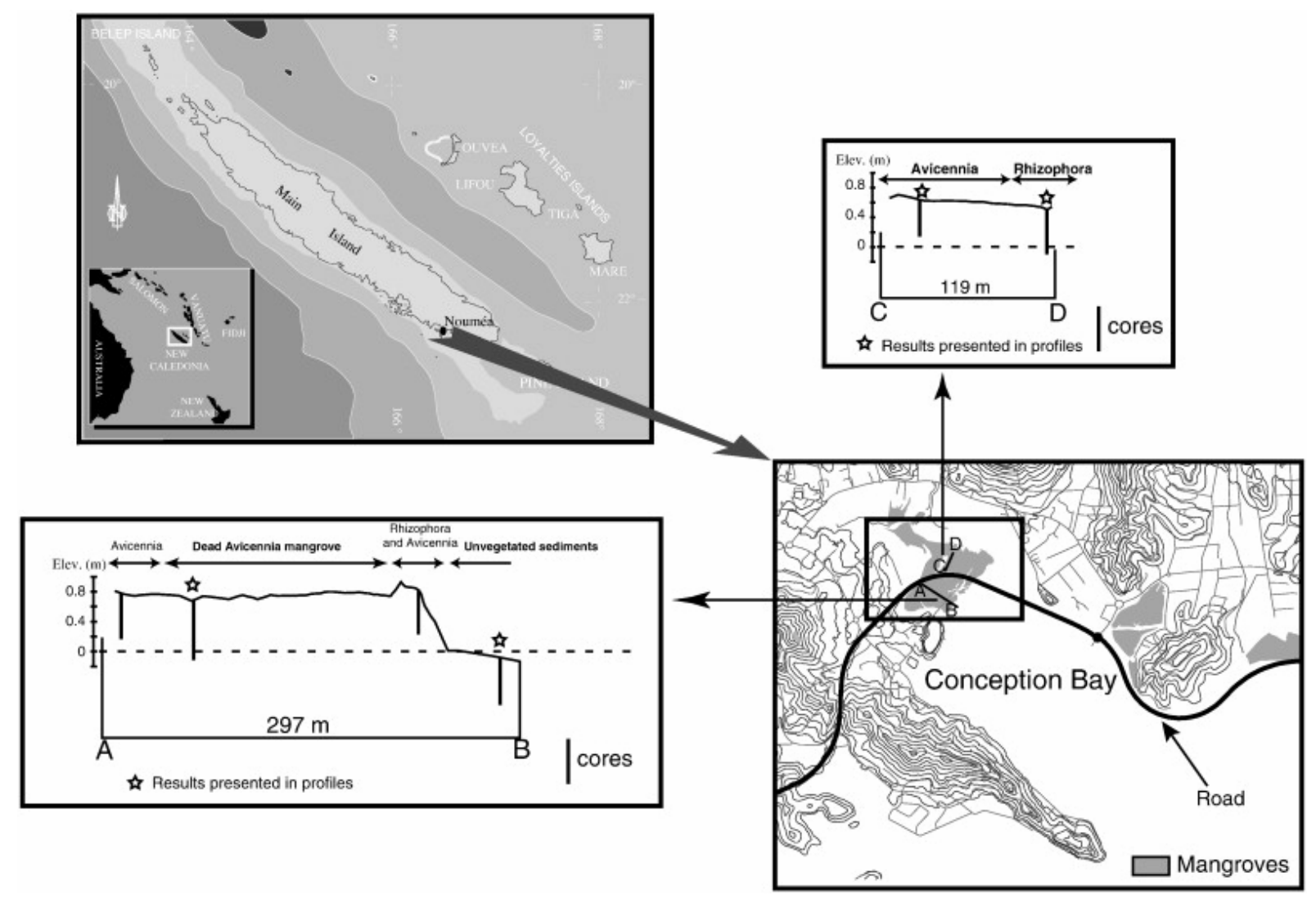

Fig. 1. Map of the studied area (Conception Bay, New Caledonia) showing: i) the localization of New

Caledonia in the Pacific Ocean; ii) the localization of the 2 studied transects in the mangrove forest of Conception bay; iii) the position of the cores along transects and their differences of elevation. 

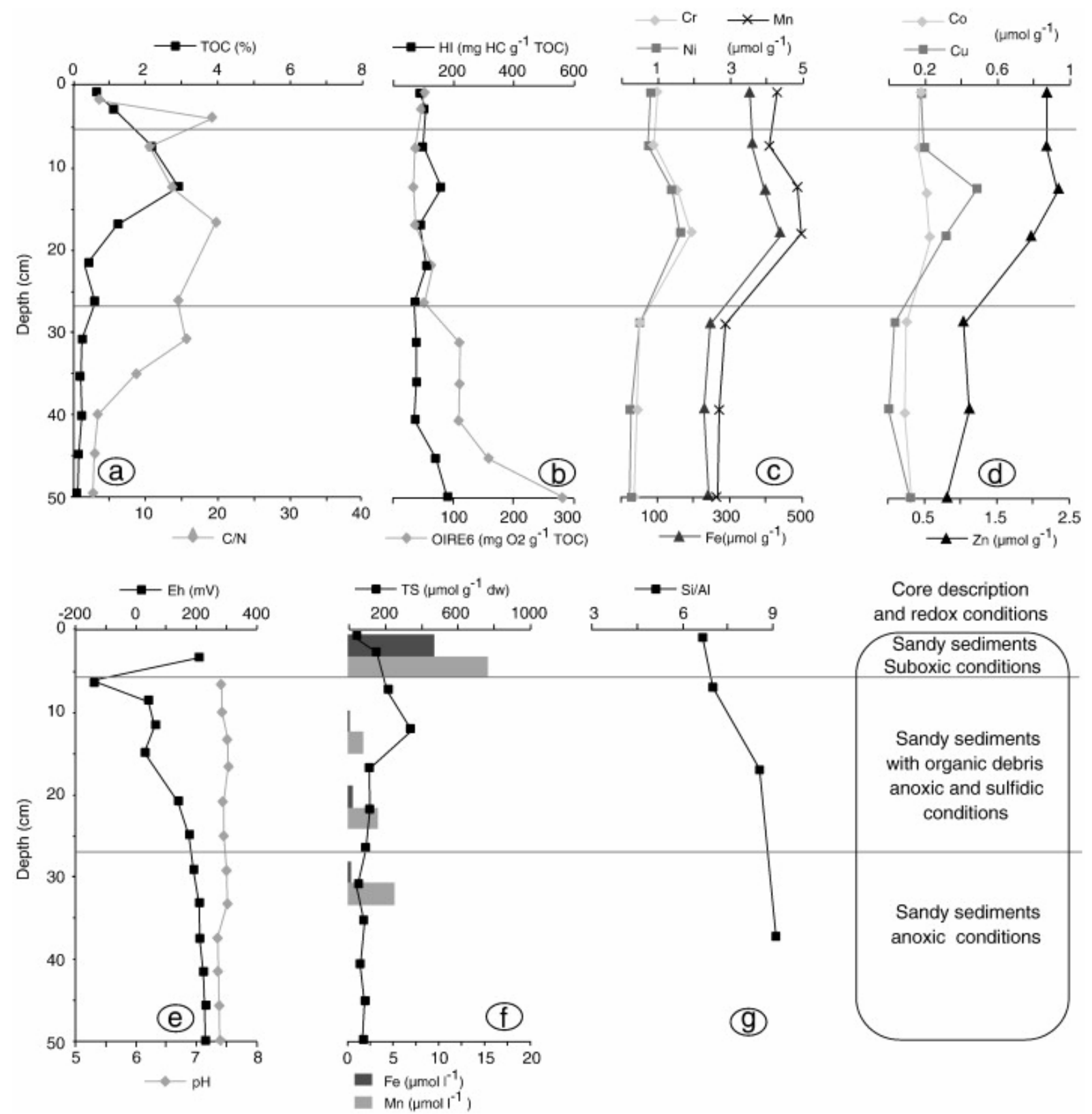

Fig. 2. Depth distribution of some parameters in the intertidal unvegetated sediment: a) TOC, $C / N ; b$ ) $\mathrm{HI}$, OIRE6; c) Fe, $\mathrm{Mn}, \mathrm{Cr}$, $\mathrm{Ni}$ in the solid phase; d) $\mathrm{Co}, \mathrm{Cu}$, and $\mathrm{Zn}$, in the solid phase; e) $\mathrm{pH}$, redox; f) TS, Fe and $\mathrm{Mn}$ in the dissolved phase, $\mathrm{g}$ ) Si/Al atomic ratios, core description. 

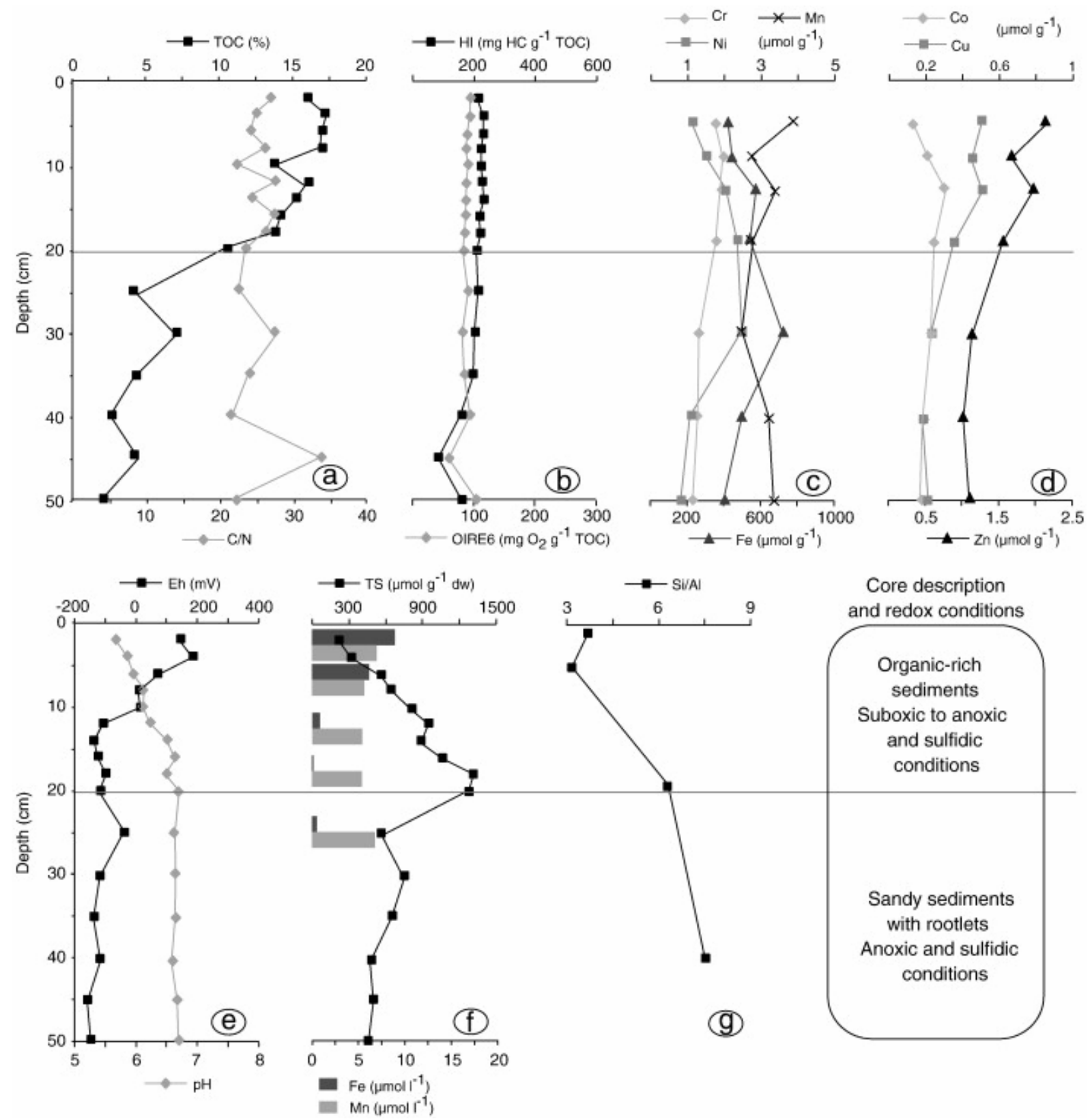

Fig. 3. Depth distribution of some parameters beneath the Rhizophora stylosa forest: a) TOC, C/N; b) $\mathrm{HI}$, OIRE6; c) Fe, $\mathrm{Mn}, \mathrm{Cr}$, and $\mathrm{Ni}$ in the solid phase; d) $\mathrm{Co}, \mathrm{Cu}$, and $\mathrm{Zn}$, in the solid phase; e) $\mathrm{pH}$, redox; f) TS, Fe and $\mathrm{Mn}$ in the dissolved phase, g) Si/Al atomic ratios, core description. 

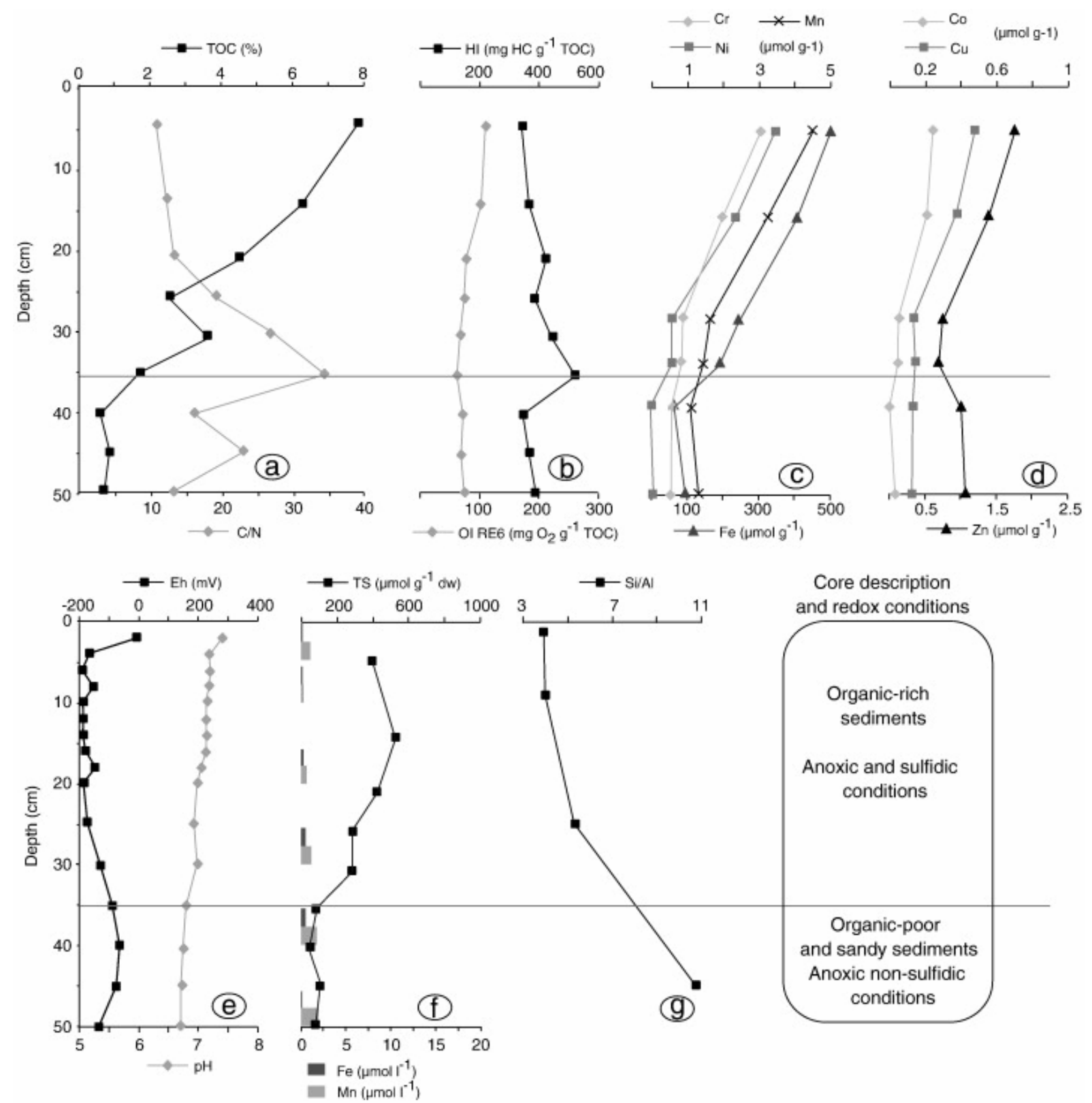

Fig. 4. Depth distribution of some parameters beneath the dead Avicennia marina forest: a) TOC,

$\mathrm{C} / \mathrm{N}$; b) HI, OIRE6; c) Fe, $\mathrm{Mn}, \mathrm{Cr}$, and $\mathrm{Ni}$ in the solid phase; d) $\mathrm{Co}, \mathrm{Cu}$, and $\mathrm{Zn}$, in the solid phase; e) $\mathrm{pH}$, redox; f) TS, Fe and Mn in the dissolved phase, g) Si/Al atomic ratios, core description. 


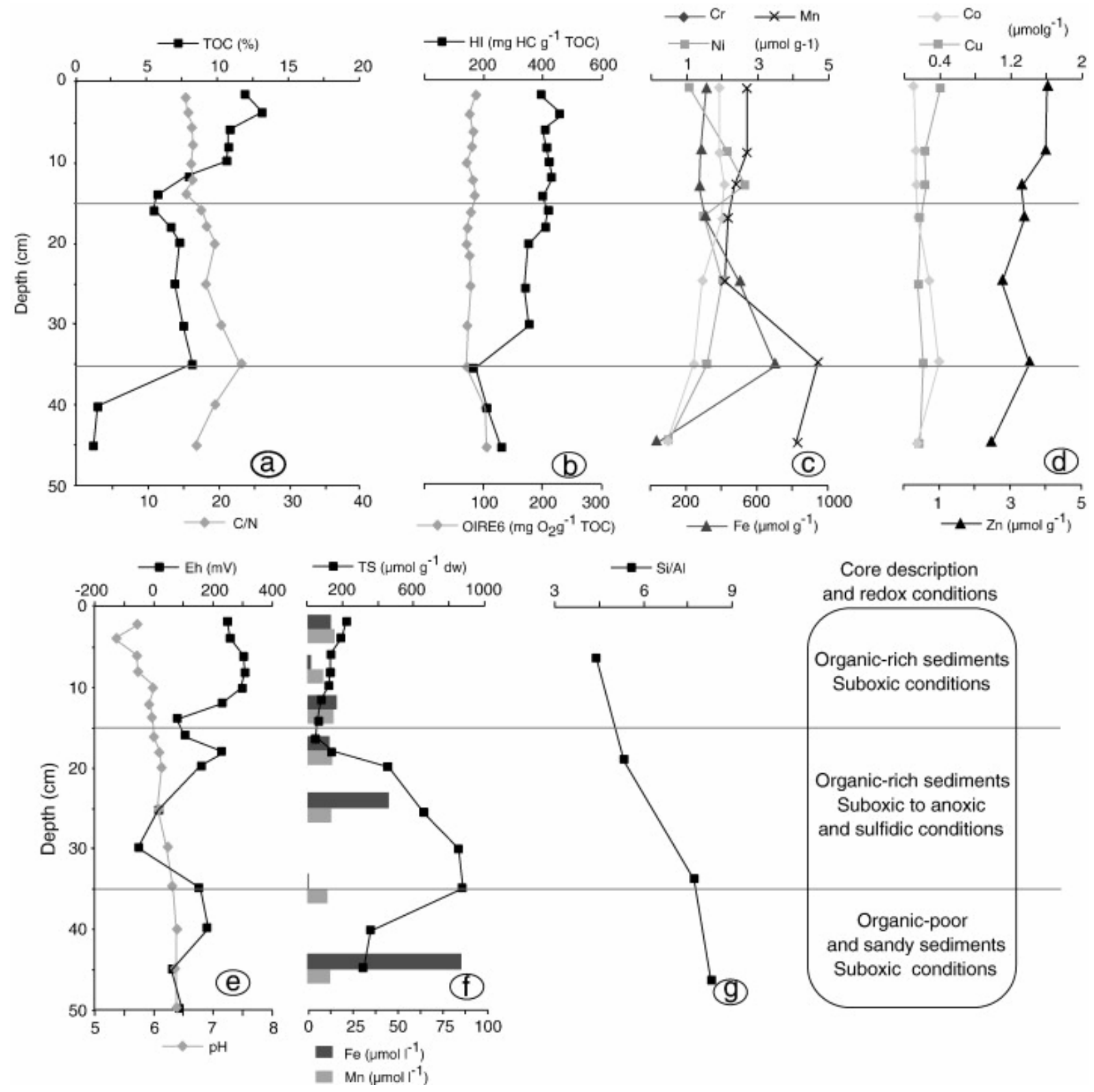

Fig. 5. Depth distribution of some parameters beneath the Avicennia marina forest: a) TOC, $C / N$; b)

$\mathrm{HI}$, OIRE6; c) Fe, $\mathrm{Mn}, \mathrm{Cr}$, and $\mathrm{Ni}$ in the solid phase; d) $\mathrm{Co}, \mathrm{Cu}$, and $\mathrm{Zn}$, in the solid phase; e) $\mathrm{pH}$, redox;

f) TS, Fe and $\mathrm{Mn}$ in the dissolved phase, g) Si/Al atomic ratios, core description. 


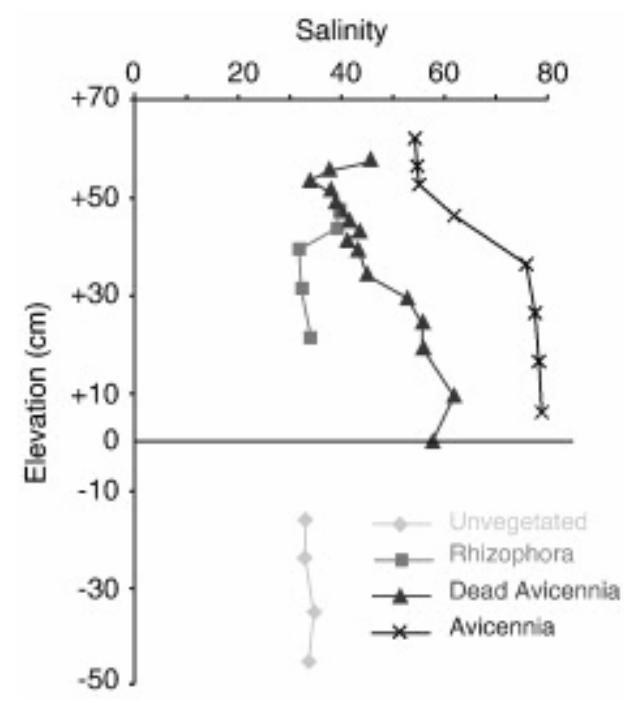

Fig. 6. Depth distribution of pore-water salinity in the various study sites. 
Tables

Table 1. Concentrations of heavy metals, TS, and TOC in cores collected in Conception Bay. Average, standard deviation (S.D.), maximum, and minimum values.

\begin{tabular}{|c|c|c|c|c|c|c|c|c|c|}
\hline & $\begin{array}{l}\mathrm{Cr} \\
(\underset{-1}{\mu \mathrm{mol} g}\end{array}$ & $\begin{array}{l}\mathrm{Cu} \\
\underset{-1}{(\mu \mathrm{mol} g}\end{array}$ & $\begin{array}{l}\mathrm{Ni} \\
\underset{-1}{(\mu \mathrm{mol} g} \mathrm{g}\end{array}$ & $\begin{array}{l}\mathrm{Zn} \\
\underset{(\mu \mathrm{mol}}{-1} \mathrm{~g}\end{array}$ & $\begin{array}{l}\text { Fe } \\
(\underset{-1}{\mu})\end{array}$ & $\begin{array}{l}\text { Mn } \\
(\underset{-1}{\mu})\end{array}$ & $\begin{array}{l}\text { Co } \\
(\underset{-1}{\mu m o l} \mathrm{~g}\end{array}$ & $\begin{array}{l}\text { TS } \\
(\% \\
)\end{array}$ & $\begin{array}{l}\text { TO } \\
\text { C } \\
(\%)\end{array}$ \\
\hline $\begin{array}{l}\text { Mean } \\
(n=4 \\
5)\end{array}$ & 1.22 & 0.22 & 1.11 & 1.35 & 331.85 & 2.90 & 0.14 & $\begin{array}{l}0.9 \\
6\end{array}$ & 4.99 \\
\hline S.D. & 0.66 & 0.12 & 0.82 & 0.44 & 175.66 & 1.05 & 0.08 & $\begin{array}{l}0.8 \\
9\end{array}$ & 5.41 \\
\hline Max. & 3.11 & 0.51 & 3.55 & 2.36 & 721.69 & 5.00 & 0.38 & $\begin{array}{l}4.0 \\
9\end{array}$ & $\begin{array}{l}21.2 \\
5\end{array}$ \\
\hline Min. & 0.36 & 0.08 & 0.03 & 0.68 & 22.64 & 1.13 & 0.01 & $\begin{array}{l}0.1 \\
2\end{array}$ & 0.2 \\
\hline
\end{tabular}

Table 2. Accuracy precision and detection limits (expressed as 3 times the standard deviation determined from numerous analyses).

\begin{tabular}{|l|l|l|l|l|l|}
\hline & $\begin{array}{l}\text { HR-ICP-AES } \\
\text { detection limit } \\
\left(\mathbf{n m o l ~ g}^{-\mathbf{1}} \mathbf{)}\right.\end{array}$ & $\begin{array}{l}\text { LGC 6137 } \\
\text { certified values } \\
\left(\mathbf{n m o l ~ g}^{-\mathbf{1}}\right)\end{array}$ & $\begin{array}{l}\text { Standard } \\
\text { deviation }\end{array}$ & $\begin{array}{l}\text { Measured } \\
\text { concentrations } \\
\left(\mathbf{n m o l} \mathbf{g}^{-\mathbf{1}} \mathbf{( n = 6 )}\right.\end{array}$ & $\begin{array}{l}\text { Standard } \\
\text { deviation }\end{array}$ \\
\hline $\mathrm{Cr}$ & 18 & 904 & 135 & 1164 & 121 \\
\hline $\mathrm{Mn}$ & 16 & 665 & 27 & 742 & 33 \\
\hline $\mathrm{Fe}$ & 291 & 30,700 & 1600 & 32,200 & 1200 \\
\hline $\mathrm{Co}$ & 25 & 232 & 29 & 206 & 28 \\
\hline $\mathrm{Ni}$ & 29 & 537 & 43 & 505 & 62 \\
\hline $\mathrm{Cu}$ & 30 & 497 & 25 & 484 & 25 \\
\hline $\mathrm{Zn}$ & 17 & 3538 & 245 & 3889 & 282 \\
\hline
\end{tabular}


Table 3. Cr and Ni concentrations depth distribution in pore-waters. UD: under the detection limit.

\begin{tabular}{|c|c|c|c|}
\hline Mangrove & Depth (cm) & $\mathrm{Cr}\left(\mu \mathrm{mol} \mathrm{I} \mathrm{l}^{-1}\right)$ & $\mathrm{Ni}\left(\mu \mathrm{mol} \mathrm{l}{ }^{-1}\right)$ \\
\hline \multirow[t]{4}{*}{ Unvegetated } & $0-5$ & UD & UD \\
\hline & $10-15$ & UD & 0.17 \\
\hline & $20-25$ & UD & 0.27 \\
\hline & $30-35$ & UD & 0.92 \\
\hline \multirow[t]{5}{*}{ Rhizophora } & $0-5$ & 0.19 & 0.59 \\
\hline & $5-10$ & 0.19 & 0.24 \\
\hline & $10-15$ & 0.21 & 0.47 \\
\hline & $15-20$ & 0.19 & 0.17 \\
\hline & $25-30$ & 0.21 & 0.2 \\
\hline \multirow[t]{7}{*}{ Avicennia } & $0-5$ & 0.38 & 1.88 \\
\hline & $5-10$ & 0.38 & 0.81 \\
\hline & $10-15$ & 0.46 & 0.8 \\
\hline & $15-20$ & 0.29 & 0.44 \\
\hline & $20-25$ & 0.33 & 0.19 \\
\hline & 30-35 & 0.21 & 0.2 \\
\hline & $40-45$ & 0.38 & 0.98 \\
\hline \multirow[t]{6}{*}{ Dead } & $0-5$ & 0.56 & UD \\
\hline & $5-10$ & 0.56 & UD \\
\hline & $10-20$ & 0.81 & UD \\
\hline & $20-30$ & 0.81 & UD \\
\hline & $30-40$ & 0.87 & UD \\
\hline & $40-50$ & 0.69 & UD \\
\hline
\end{tabular}


Table 4. Characteristics of fresh mangrove tissues (TOC, C/N, HI, and OIRE6).

\begin{tabular}{|c|c|c|c|c|}
\hline Samples & TOC & $\mathbf{C} / \mathbf{N}$ & HI & OIRE6 \\
\hline & $(\%)$ & & $\left(\mathrm{mg} \mathrm{HC} \mathrm{g} \mathrm{g}^{-1} \mathrm{TOC}\right)$ & $\left(\mathrm{mg} \mathrm{O}_{2} \mathrm{~g}^{-1} \mathrm{TOC}\right)$ \\
\hline A. marina leaf & 40 & 20 & 569 & 127 \\
\hline A. marina wood & 37 & 43 & 405 & 152 \\
\hline R. stylosa leaf & 38 & 40 & 529 & 92 \\
\hline R. stylosa wood & 43 & 91 & 341 & 89 \\
\hline
\end{tabular}

Table 5. Correlation half matrix $(n=45)$. Bold print indicate correlation higher than 0.5.

\begin{tabular}{|l|l|l|l|l|l|l|l|l|}
\hline & $\mathrm{Cr}$ & $\mathrm{Cu}$ & $\mathrm{Ni}$ & $\mathrm{Zn}$ & $\mathrm{Fe}$ & $\mathrm{Mn}$ & $\mathrm{TS}$ & $\mathrm{TOC}$ \\
\hline $\mathrm{Cr}$ & 1. & & & & & & & \\
\hline $\mathrm{Cu}$ & $\mathbf{0 . 7 6}$ & 1. & & & & & & \\
\hline $\mathrm{Ni}$ & $\mathbf{0 . 8 8}$ & $\mathbf{0 . 5 7}$ & 1. & & & & & \\
\hline Zn & 0.47 & $\mathbf{0 . 6 6}$ & 0.32 & 1.000 & & & & \\
\hline Fe & 0.54 & 0.49 & $\mathbf{0 . 6 8}$ & 0.29 & 1. & & & \\
\hline Mn & 0.31 & 0.46 & 0.27 & $\mathbf{0 . 6 0}$ & 0.43 & 1. & & \\
\hline TS & 0.35 & 0.47 & $\mathbf{0 . 5 1}$ & 0.08 & $\mathbf{0 . 7 3}$ & 0.11 & 1. & \\
\hline TOC & $\mathbf{0 . 6 7}$ & $\mathbf{0 . 7 3}$ & $\mathbf{0 . 5 6}$ & 0.38 & 0.47 & 0.01 & $\mathbf{0 . 5 9}$ & 1. \\
\hline
\end{tabular}

